\title{
Bacterial Flagellum versus Carbon Nanotube: A Review Article on the Potential of Bacterial Flagellum as a Sustainable and Green Substance for the Synthesis of Nanotubes
}

\author{
Charles Ng Wai Chun ${ }^{1}$, Husnul Azan Tajarudin ${ }^{1, *}$, Norli Ismail ${ }^{2}$, Baharin Azahari ${ }^{3}$, Muaz Mohd Zaini Makhtar ${ }^{1}$ \\ and Leong Kah Yan ${ }^{1}$ \\ 1 Bioprocess Technology Division, School of Industrial Technology, Universiti Sains Malaysia, Penang 11800, \\ Malaysia; charlesngwaichun@student.usm.my (C.N.W.C.); muazzaini@usm.my (M.M.Z.M.); \\ kahyan6007@gmail.com (L.K.Y.) \\ 2 Environmental Division, School of Industrial Technology, Universiti Sains Malaysia, Penang 11800, Malaysia; \\ norlii@usm.my \\ 3 Bioresource, Paper and Coatings Division, School of Industrial Technology, Universiti Sains Malaysia, Penang \\ 11800, Malaysia; baharin@usm.my \\ * Correspondence: azan@usm.my
}

check for updates

Citation: Chun, C.N.W.; Tajarudin, H.A.; Ismail, N.; Azahari, B.; Makhtar, M.M.Z.; Yan, L.K. Bacterial Flagellum versus Carbon Nanotube: A Review Article on the Potential of Bacterial Flagellum as a Sustainable and Green Substance for the Synthesis of Nanotubes. Sustainability 2021, 13, 21. https://dx.doi.org/doi:10.3390/su 13010021

Received: 14 November 2020 Accepted: 10 December 2020 Published: 22 December 2020

Publisher's Note: MDPI stays neutral with regard to jurisdictional claims in published maps and institutional affiliations.

Copyright: () 2020 by the authors. Licensee MDPI, Basel, Switzerland. This article is an open access article distributed under the terms and conditions of the Creative Commons Attribution (CC BY) license (https: / / creativecommons.org/ licenses/by/4.0/).

\begin{abstract}
Bacterial flagella are complex multicomponent structures that help in cell locomotion. It is composed of three major structural components: the hook, the filament and basal body. The special mechanical properties of flagellar components make them useful for the applications in nanotechnology especially in nanotube formation. Carbon nanotubes (CNTs) are nanometer scale tube-shaped material and it is very useful in many applications. However, the production of CNTs is costly and detrimental to the environment as it pollutes the environment. Therefore, bacterial flagella have become a highly interesting research area especially in producing bacterial nanotubes that could replace CNTs. In this review article, we will discuss about bacterial flagellum and carbon nanotubes in the context of their types and applications. Then, we will focus and review on the characteristics of bacterial flagellum in comparison to carbon nanotubes and subsequently, the advantages of bacterial flagellum as nanotubes in comparison with carbon nanotubes.
\end{abstract}

Keywords: bacterial flagella; bacterial nanotubes; carbon nanotubes; applications of bacterial flagella; applications of carbon nanotubes

\section{Introduction}

Bacteria, well known for its diminutive size, typically a few microns in length, were among the first life forms and the simplest organisms to evolve on earth [1]. Bacteria is also very useful in many applications, it can be used in the production of useful chemicals, animal feeds, iron removal as well as electricity generation [2-5]. Bacterial flagella, as a part of the bacterial cell, is also a very useful component, Bacterial flagella are long, hairy filamentous organelles that support the locomotion of cells. They aid in the movement of cells across the surface or in liquids so that cells can travel to and from external conditions. In certain instances, the cells will move towards favourable environments [6]. The use of bacterial flagella in various applications in recent years has been a highly important research among scientists, particularly biologists and biotechnologists worldwide. Some of the factors contributing to this trend is that it is simple to produce bacterial flagella in a large quantity and most significantly it is environmentally safe. It is reported by Benita et al. (2000) that flagella display has been used in peptide display as an alternative to the phage-display technique. Flagella have also been shown to play a significant role in bacterial pathogenesis [7]. From here, we could see that bacterial flagella have been used quite widely among the researchers in different fields. 
Carbon nanotubes (CNTs) are tubes that typically measured in nanometers, consisting of carbon with diameters. These are structures of cylindrical shape that compose of carbon atoms, called graphene. There are several types of CNTs, examples included singlewalled nanotubes of carbon (SWNTs) and multi-walled nanotubes (MWNTs). CNTs have been used in several applications from diverse fields since the 2000s, for example in the biomedical sector. For therapeutics, CNTs have been used in medicine and pharmacy for the drug delivery purposes. These have therefore drawn tremendous interest in biological and biomedical technologies [8].

Recent progress in bacterial flagella research and development as nanotubes makes it close to carbon nanotubes when it comes to the application part. Carbon nanotubes are very useful in different fields, but CNT processing can be detrimental to the environment and very expensive. Work on bacterial flagella as nanotubes, which have the same properties as carbon nanotubes, is also very encouraging because its processing is both environmentally sustainable and cost-efficient. This, this review article will discuss about the bacterial flagellum and carbon nanotubes in the context of their types and applications. Then, we will focus on the characteristics of bacterial flagellum in comparison to carbon nanotubes and subsequently, the advantages of bacterial flagellum as nanotubes in comparison with carbon nanotubes.

\section{The Bacterial Flagellum}

Bacterial flagella are long hairy structures with complex multicomponents. It is a complicated structure that has more than 20 distinct proteins assembled and created. Bacteria may have one, many or even more flagellum [9]. These can be present only at one end or on both ends of a bacterium or peritrichous, indicating that the flagella can be spread all along the surface (4). Flagella performs several roles in multiple activities, such as cell motility, protein and DNA secretion and absorption, adhesion and penetration of the host, conductance or cellular encapsulation [10]. Besides motility, which is the main function of flagella, it also participates in the formation of biofilms [9]. Biofilm formation is a crucial part of bacteria's lifestyle, as it increases the protection of bacteria against antibiotics and host defenses [11]. The flagellum is one of the only biological devices that can spin $360^{\circ}$ continuously, powered by one of the most efficient motors compared to its scale [12]. The main source of power that drive the motor of bacterial flagellar motor is ion motive force (IMF). The power is produced by transmembrane electrochemical ion gradient and flagellar filament rotation to produce thrust and momentum for the cell body to be propelled [13]. Apart from its functions in the field of cell motility and other aspects, the organized and multi-copy build-up of flagella has led to its biotechnology applications as bacterial nanotubes, display and secretion tools, molecular motors or therapeutic targets [10]. The bacterial flagella could be isolated from the bacteria by many methods. However, different strains of bacteria could have different methods of isolation as to date, there are still lack of documents or findings which stated the standard method in isolating bacterial flagella. For instance, the flagella of Methanococcus voltae were isolated by shearing the cells to release the filaments, which were purified by differential centrifugation and banding in $\mathrm{KBr}$ gradients. Then, the purification of intact flagella (filament, hook, and basal body) could be achieved by using phase transition separation with Triton X-114 [14].

\subsection{Flagellar Structure}

The flagellum has a very unique structure and is generally described as consisting of three main structural components: the hook, the filament and the basal body [15] (Refers to Figure 1). It is a complex composed of more than 20 proteins [16]. The flagella of each bacterial species are specifically characterized and appear in defined numbers and at distinct locations. The flagella pattern is customized and adjusted to make movement of the cell more efficient within the species' corresponding environment. Bacteria with polar flagella, for example, allow them to swim quickly in liquid environments while bacteria with peritrichous flagella allow them to move easily through more viscous environments 
or across surfaces [17]. The structures of the basal body consist of the MS ring, the C ring, the protein export apparatus and the rod where the organization of the basal body are well conserved [6] (Refers to Figure 1). The basal body's C ring, also known as the flagellar cytoplasmic ring connects to the MS ring which has a socket-like area where the rod is anchored [18]. These structures ensure that the flagella which is projected out from the body of the bacteria can hold firm and be able to perform its functions. Table 1 shows the types of flagellum and its attributes. Figure 2 shows the visualization of flagella using phase-contrast microscopy and transmission electron microscope [19].

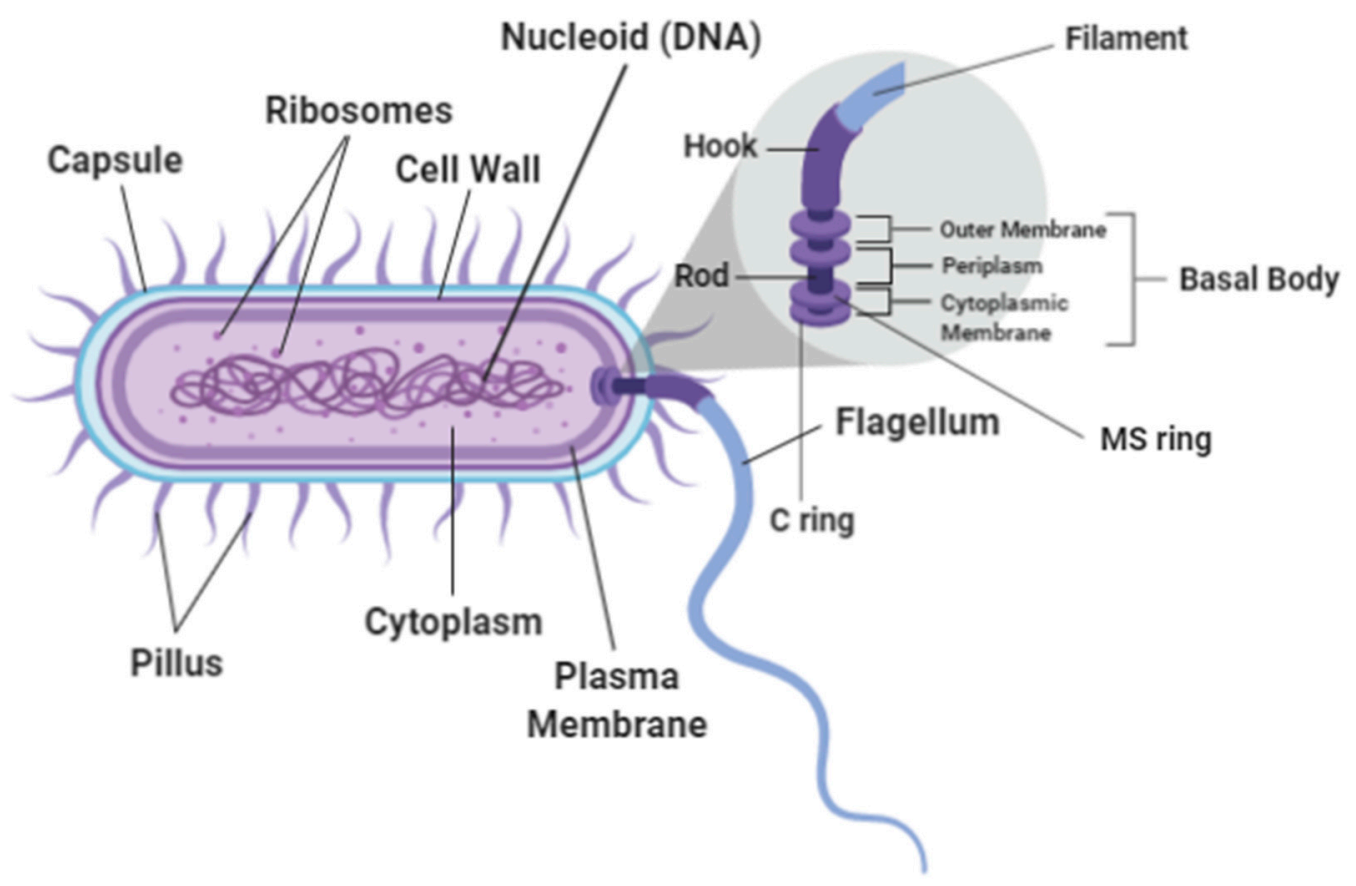

Figure 1. Bacterial Flagellum.

Table 1. Types of flagellum and its attributes.

\begin{tabular}{cl}
\hline Type of Flagellum & \multicolumn{1}{c}{ Characteristics } \\
\hline Monotrichous & $\begin{array}{l}\text { Only a flagellum } \\
\text { extends from one end } \\
\text { of the cell. }\end{array}$ \\
Amphitrichous & $\begin{array}{l}\text { A single or multiple } \\
\text { flagella extend from } \\
\text { both ends of the cell. }\end{array}$ \\
Lophotrichous & $\begin{array}{l}\text { Several flagella that } \\
\text { extend from one end } \\
\text { of the cell. }\end{array}$ \\
Peritrichous & $\begin{array}{l}\text { Multiple flagella that } \\
\text { randomly distribute } \\
\text { over the entire cell. }\end{array}$
\end{tabular}




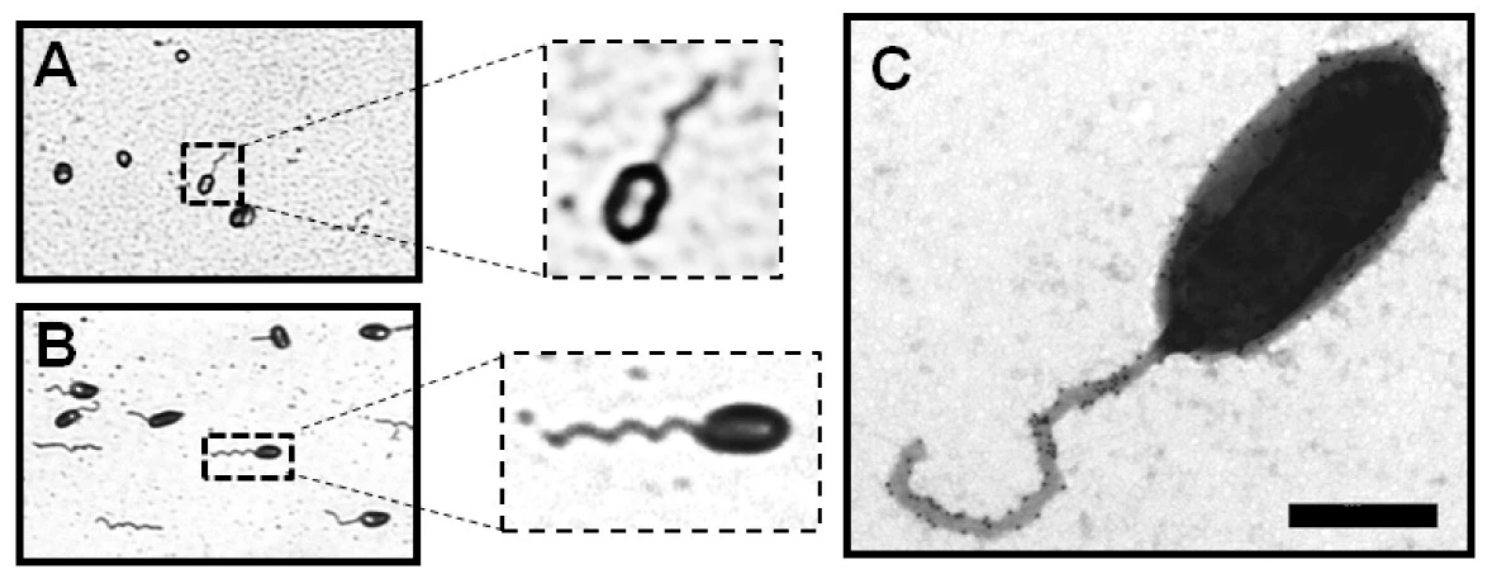

Figure 2. Visualization by phase-contrast microscopy of gram-negative bacterial flagella: (A) Brucella melitensis and (B) Caulobacter crescentus. (C) Negative-staining TEM image of the sheathed polar flagellum of B. melitensis. Bar, $500 \mathrm{~nm}[19]$.

\subsection{Flagellar Motor}

Flagellum is a complex molecular motility machine which consists of a helical propeller, a rotary engine and a universal joint. Given the flagella's complexity and structural variation between bacterial organisms, flagella-possessing bacteria often share a specific rotary nanomachine that is the flagellar engine at the base of the filament. Bacteria swim using the tiny rotary motors which power helical flagella rotation. It is a highly efficient rotating machine and is energized by an ion gradient that generated through the bacteria's cell membrane [20]. The motor consists of a complex ring of rotor and several units of stator which serve as a channel of transmembrane proton for conducting protons [13]. The ion flux would then be transformed into the mechanical function or torque necessary for the rotation of the motor through an ion channel of each stator device [21]. The engine speed is determined by the number of stators that are present. The motor speed will improve if more stators are hired [22]. The number of stators within the engine depends on the price. A motor can have up to 11 docked stators at heavy or low loads, while the motor may usually only operate with one stator at moderate loads or high speeds [23]. Flagella will move and react to surrounding stimulus. The flagella signal transducer will transmit environmental signals via a cytoplasmic chemotactic signaling pathway to the motor. The intracellular chemotactic signaling pathways will regulate the direction of flagella-driven motility in reaction to changes in the environment, allowing bacteria to migrate and transfer to more appropriate conditions for their survival [13].

\subsection{Types of Flagella}

There are essentially four distinct forms of bacterial flagellum with separate flagellar arrangements, namely, monotrichous, amphitrichous, lophotrichous and peritrichous. It is said that a bacterium is monotrichous if there is only one flagellum extending from one cell's end. Amphitrichous bacteria have a single or numerous flagellum that spreads from both cell ends. Lophotrichous bacteria have several flagella that stretch from one end of the cell and peritrichous bacteria have several flagella that disperse uniformly throughout the bacteria cell [24]. Also, flagella can be classified as polar flagella or peritrichous flagella in a different way. Monotrichous, amphitrichous and lophotrichous flagella are known to be polar flagella since one or more flagella originate from either or both ends of the bacteria, whereas peritritichous flagella bacteria have lateral flagella spread along the bacteria's cell surface. As the flagella is found in the body, peritrichous flagella is not called polar. These flagella will move both in clockwise direction and in counterclockwise direction. A change in the direction of the clockwise will push the organism forward while a step in the direction of the counterclockwise moves the organism backward. If such flagella spin in 
counterclockwise motion, they can create an assembly that propels the organism in one direction, Therefore, if any of the flagella falls free and starts to spin in the direction of the clockwise movement in another movement, the organism will instead be in a tumbling motion that can contribute to the stationary motion of the organism because it will no longer travel in any particular direction.

\section{Applications of Bacterial Flagella}

The mechanical properties of flagellar components such as the basal body, hook and filament increase scientists' interest in exploring its applications especially in the field of nanotechnology as these flagellar components may provide a template for useful atomicscale structures. The hook and the flagella filament were well studied particularly with regard to their layout and functions for both cryo-EM maps and x-ray crystal structures, as the hook may serve as a universal nanoscale joint whereas the filament can be mechanically transferred [25]. The structured and natural roles of flagella have contributed to their biotechnological applications in several areas, such as using them as therapeutic targets, show and secretion instruments or as molecular motors [10]. Table 2 shows the example of previous studies about applications of flagella by researchers.

Table 2. Example of previous studies about applications of flagella by researchers.

\begin{tabular}{cc}
\hline Application & Reference \\
\hline Biotemplated Nanomaterials for Electronics & {$[26,27]$} \\
Templates for Silica Fibers & {$[28]$} \\
Nanoswimmers & {$[29,30]$} \\
Nanotubes Formation & {$[31]$} \\
\hline
\end{tabular}

\subsection{Bacterial Flagella as Biotemplated Nanomaterials for Electronics}

Biotemplates of bacteria or microbial origin are a modern source of materials used in the design and manufacture of complex, large surface area structures with great potential for nanotechnology applications. Such biotemplates are very useful for the synthesis of nano-structural or micro-structural materials [26].

Bacterial flagella has very unusual structural properties that have been shown to be of consistency and promising biotemplates, and can be used to build nanomaterials of very large surface area. The flagella surfaces are chemically modifiable and require to modify the possession of electrical or electronic products. Their unique and extraordinary physical properties also render them ideal work systems to enhance nanoelectronics, as there are many possibilities for manipulation.

Most bacteria possess a variety of fine and unique features such as distinctive nanostructures or microstructures. Enabling the use of these naturally formed specific structures as biotemplates is thus very useful and helpful for constructing complicated structures for numerous applications, such as nanoelectronics. Biotemplating is a cost-efficient and successful method to synthesize dramatically electrical components for microstructures and nanostructures. Complex and costly processes are not needed in the method, therefore this biotemplate technology is feasible and suitable for the synthesis of nanomaterials with large surface area [27]. Table 3 shows the examples of electronics produced by bacterial flagella.

Table 3. Examples of electronics produced by bacterial flagella.

\begin{tabular}{cc}
\hline Electronics & References \\
\hline Dye-Sensitized Solar Cell (DSSC) & {$[27]$} \\
Lithium Ion Battery (LIB) & {$[27]$} \\
Osteogenic Differentiation Nano-Promoter & {$[32]$} \\
Bioactuator and Biosensor & {$[33]$} \\
\hline
\end{tabular}




\subsection{Bacterial Flagella as Templates for Silica Fibers}

Silica fibers are fibers that made of sodium silcate or water glass. It is often also named as aluminosilicate fibers [34]. They are normally used in heat protection and in packings and compensators.

aFlagellum is a self-assembled nanotube framework from a large number of a subunit named flagellin. Genetically modified may be the solvent-exposed domain of growing flagellin on the flagella, and therefore an external peptide can be genetically integrated into the flagellin domain, resulting in the high-density presence of this external peptide on the surface of the flagella.

Genetically modified flagella may be removed and used as models on the surface of the flagella to form silica sheaths where double layered silica or flagellar nanotubes are made. The flagella templates inside the silica or flagellar nanotubes are then extracted by calcinating the nanotubes to generate silica nanotubes at a high temperature of $550{ }^{\circ} \mathrm{C}$. It is shown that silica-flagella nanotubes can be used for selective coating of gold nanoparticle on nanotubes. Flagella may also show various peptides, resulting in specific morphologies of the silica nanotubes [28].

\subsection{Biotemplated Bacterial Flagellar as Nanoswimmers}

Nanoswimmers are a device that attached with nanomotor that work under the principle of bacterial flagella motion. It is a designed device for biomedical field.

The nanoswimmer uses repolymerized bacterial flagella as a biomineralising nanotemplate. Through simulating the behavior of the bacterial flagella engine utilizing continuous rotating magnetic fields, it would demonstrate the swimming properties of this silicatemplated flagella and the capacity to control its trajectories wirelessly. The templated nanotubes can be generated with distinct helical geometries utilizing various alkaline $\mathrm{pH}$ values to correct the polymorphic structure of the flagella templates. Porous hollow biotemplated nanoscale helix from bacterial flagella which can serve as robotic swimmer with a low number of Reynolds.

These fuel-free nanoscale machines will benefit from numerous fields of the medical industry, including delivery of drugs, biopsy and precision nanosurgery of diagnostic research [29]. It is shown that the bacterial flagellar nanoswimmer may be a cost-effective solution to existing helical nanorobots development methods [30].

\subsection{Mineralization of Bacterial Flagella for Nanotube Formation}

Nanotubes are organic or inorganic, self-assembled sheets of atoms organized in tubes of single-walled or multi-walled structures. They are nanometers in size and have a large internal volume [35]. Nanotubes are a very distinctive class of materials as their properties depend not only on their compositions but also on their geometry [36]. Bacterial nanotubes are nanotubes shaped by bacterial flagella. These are membranous intercellular bridges which bind nearby neighboring cells [37].

Bacteria-isolated flagella can be used as a basis for the creation of bacterial nanotubes, rendered and achieved by developments in the production of ceramic film at low temperatures. This method will be carried out using the Titanium dioxide chemical compound, TiO2. Through aqueous water, $\mathrm{TiO}_{2}$ is precipitated on the surface of the bacterial flagella. This method is less cumbersome and more beneficial than other methods of mineralization, as the method does not involve genetic alteration of the bacterial flagella. Additionally, mineralization is carried out at low temperatures in aqueous solution, which in turn will greatly minimize development costs [38]. Figure 3 shows the mineralization of bacterial flagellum. 


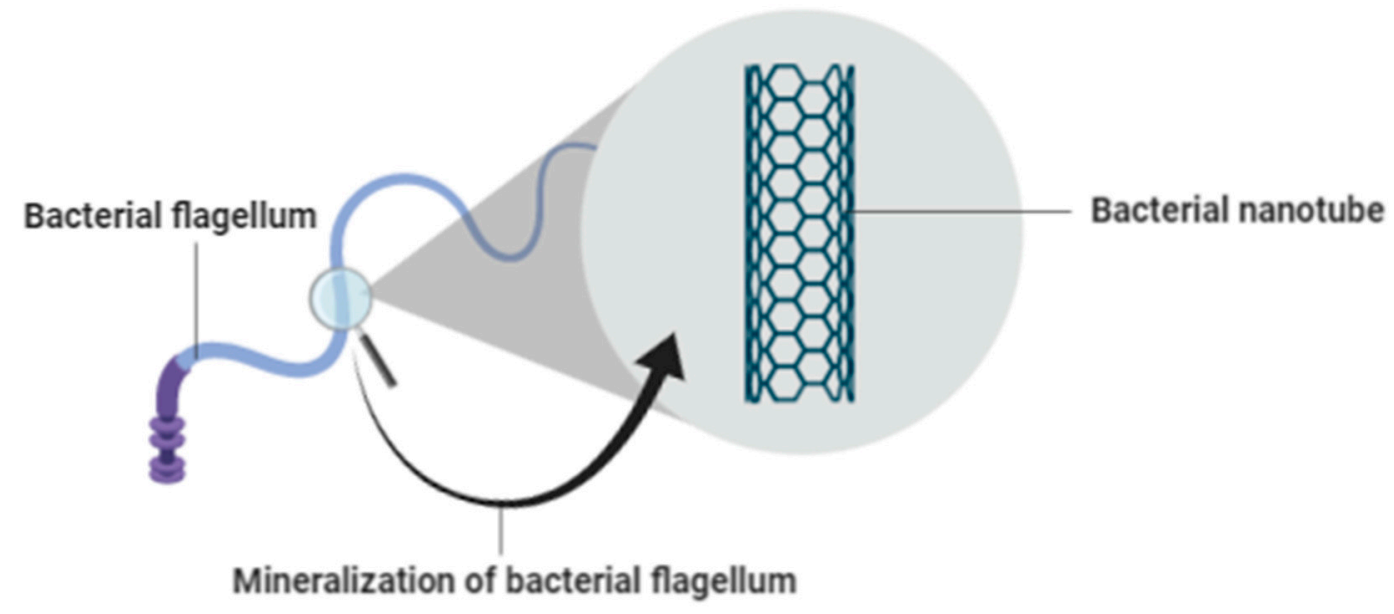

Figure 3. Mineralization of Bacterial Flagellum.

Bacterial nanotubes may be used in multiple uses, for example in the production of medicines, semiconductors and more. It is an excellent alternative for carbon nanotubes, because it is both environmentally sustainable and cost-efficient.

\section{Synthesis of Nanotubes from Bacterial Flagella}

Bacterial flagella are self-assembled protein nanofibers which are highly prospective in synthesizing nanotubes to replace the carbon nanotubes that are now widely used in many areas. Apart from the synthesis of nanotubes using titanium dioxide, $\mathrm{TiO}_{2}$ as described above, another more extensively studied method of synthesizing flagella nanotubes is by using silica as the coating. Throughout the phase, bacterial flagella should be used as a biological template and the resulting nanotubes are the silica nanotubes (SNTs) with morphologies that are able to be controlled. Under moderate conditions SNTs can be synthesized in aqueous solutionIn general, as $\mathrm{pH}$ ranges from acidic to alkaline, SNTs range from bundled coiled to typical sinusoidal waves, straight and helical morphologies [39]. The surface features and morphologies of flagella-templated SNTs can be simply adjusted with $\mathrm{pH}$ value or surface chemistry of flagella. SNTs with distinct morphologies such as smooth, coiled, helical and curly growing be shaped using similar wavelengths based on various models. Various surface properties can also be collected, such as rough, smooth and granular SNTs [40]. Overall, bacterial flagella are promising biotemplates for developing a cost-efficient and environmentally benign nanotubes.

\section{Carbon Nanotubes (CNTs)}

A Carbon Nanotube is a tube-shaped substance constructed of carbon on a nanometer scale. The graphite coating behaves like a rolled-up chicken wire with consistent unbroken hexagonal structures at the hexagonal apexes where the carbon molecules are found. Carbon nanotubes have several structures which differ in thickness, weight, number of layers, helicity form and amount. Bacterial nanotubes may be used as metals, or as semiconductors often used. Therefore, while these bacterial nanotubes are made from the same graphite layer, their electrical characteristics can differ according to the variations as described, making this a very promising area to explore [41].

\section{Types of Carbon Nanotubes (CNTs)}

There are basically three categories of CNTs based on the number of tubes present in it. The three types of CNTs are single-walled, double-walled and multi-walled. Single-walled CNTs (SWNTs) consist of a single layer of graphene folded into itself, with a diameter of 1-2 $\mathrm{nm}$. The duration of the nanotubes can vary due to the various preparation methods. Double-walled CNTs nanotubes are composed of two condensed carbon nanotubes under which the outer tube encloses the inner tube and multi-walled CNTs are constructed of sev- 
eral layers of graphene rolling into themselves with diameters of between 2 to $50 \mathrm{~nm}$ based on the amount of usable graphene tubes. Such MWNTs have an average gap of $0.34 \mathrm{~nm}$ across layers [42]. Table 4 shows the types of carbon nanotubes (CNTs) and its attributes. Figure 4 shows the TEM image of single-walled carbon nanotubes (SWCNT) [43]. Figure 5 shows high resolution TEM images of double-walled carbon nanotubes (DWCNTs) [44] and Figure 6 shows TEM images of multi-walled carbon nanotubes (MWCNTs) [45]. Figure 4 shows the TEM image of single-walled carbon nanotubes (SWCNT) where the diameter of the nanotube is about $1 \mathrm{~nm}$.

Table 4. Types of Carbon Nanotubes (CNTs) and its attributes.

\begin{tabular}{|c|c|c|c|}
\hline $\begin{array}{c}\text { Type of Carbon } \\
\text { Nanotubes (CNTs) }\end{array}$ & Characteristics & Applications & Reference \\
\hline $\begin{array}{l}\text { Single-walled CNTs } \\
\text { (SWNTs) }\end{array}$ & $\begin{array}{l}\text { A single graphene sheet rolled } \\
\text { upon itself with a diameter of } \\
1-2 \mathrm{~nm} \text {. }\end{array}$ & $\begin{array}{l}\text { Nanoporous filters, } \\
\text { catalyst supports, } \\
\text { solar collector. }\end{array}$ & {$[42]$} \\
\hline $\begin{array}{l}\text { Double-walled CNTs } \\
\text { (DWNTs) } \\
\text { (DW }\end{array}$ & $\begin{array}{l}\text { Two concentric carbon } \\
\text { nanotubes in which the outer } \\
\text { tube encloses the inner tube. }\end{array}$ & $\begin{array}{l}\text { Gas sensors, field } \\
\text { emission displays, } \\
\text { imaging and } \\
\text { therapeutic agents. }\end{array}$ & [42] \\
\hline $\begin{array}{l}\text { Multi-walled CNTs } \\
\text { (MWNTs) }\end{array}$ & $\begin{array}{l}\text { Multiple layers of graphene } \\
\text { rolled upon itself with } \\
\text { diameters of about } 2 \text { to } 50 \mathrm{~nm} \text {. }\end{array}$ & $\begin{array}{l}\text { Catalysts, electron } \\
\text { field emitters, sensors, } \\
\text { nanolithography. }\end{array}$ & [42] \\
\hline
\end{tabular}

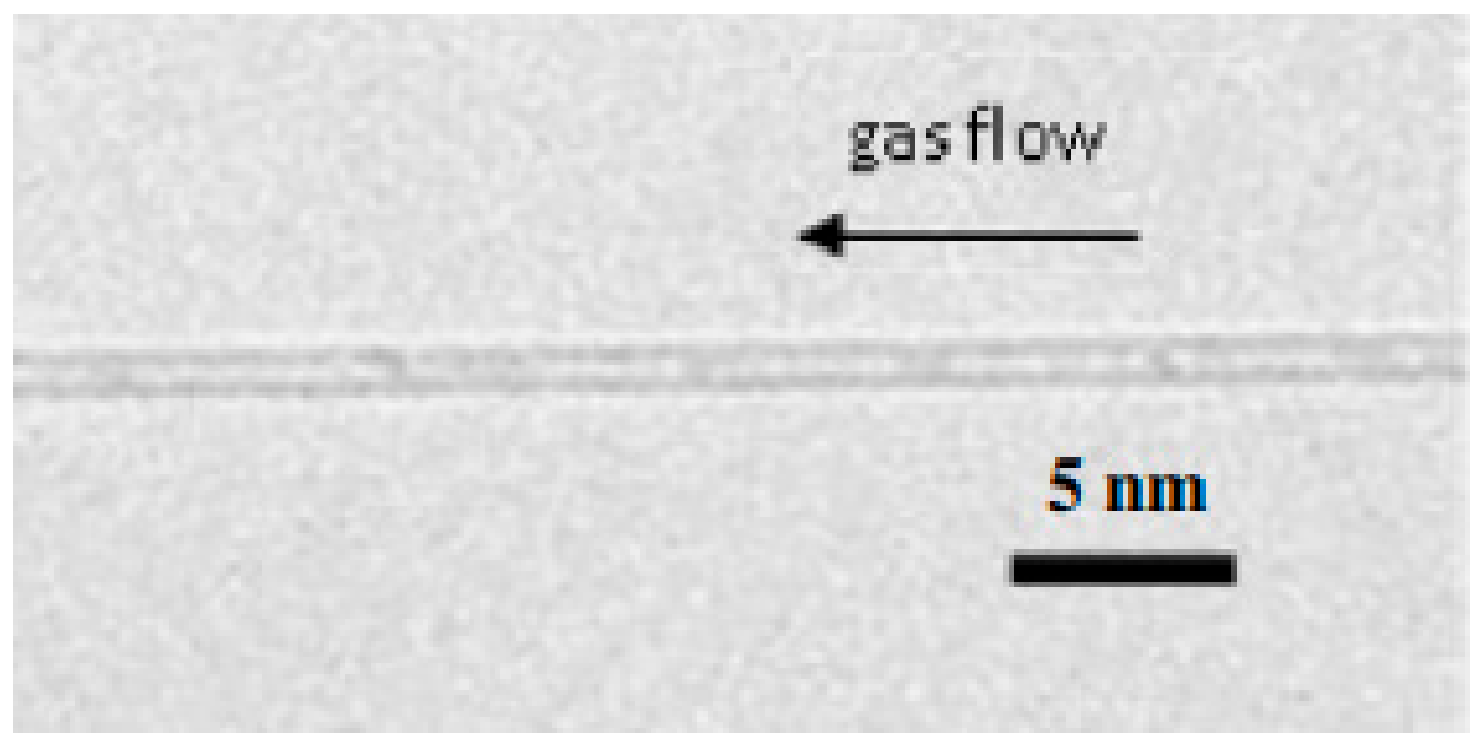

Figure 4. TEM image of single-walled carbon nanotubes (SWCNT). The diameter of the nanotube is about $1 \mathrm{~nm}$ [43]. 


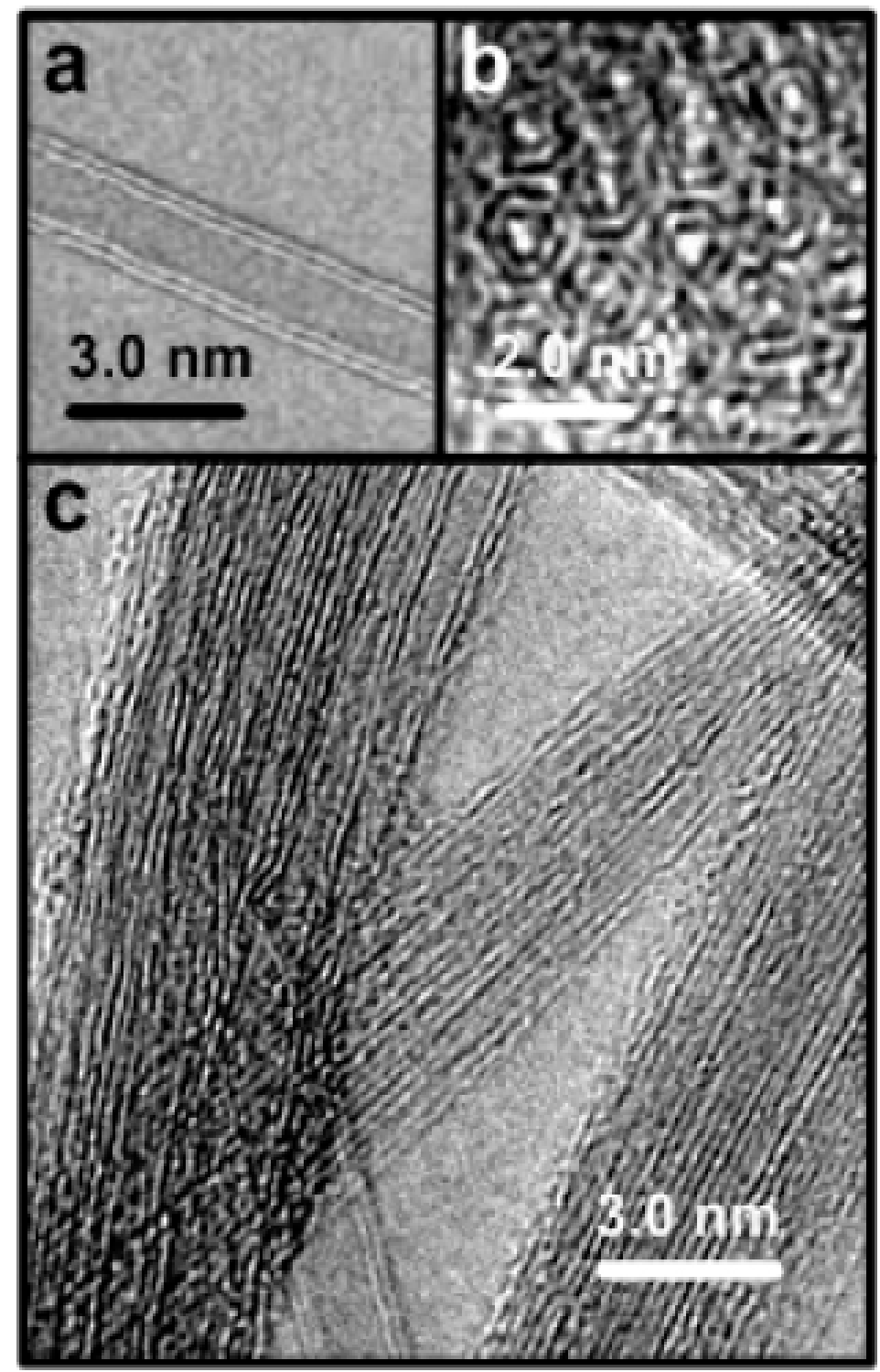

Figure 5. High resolution TEM (HRTEM) images of double-walled carbon nanotubes (DWCNTs) after purification. (a) An individual double-walled nanotube; (b) End of a bundle containing doublewalled nanotubes; (c) A larger view of the sample [44].
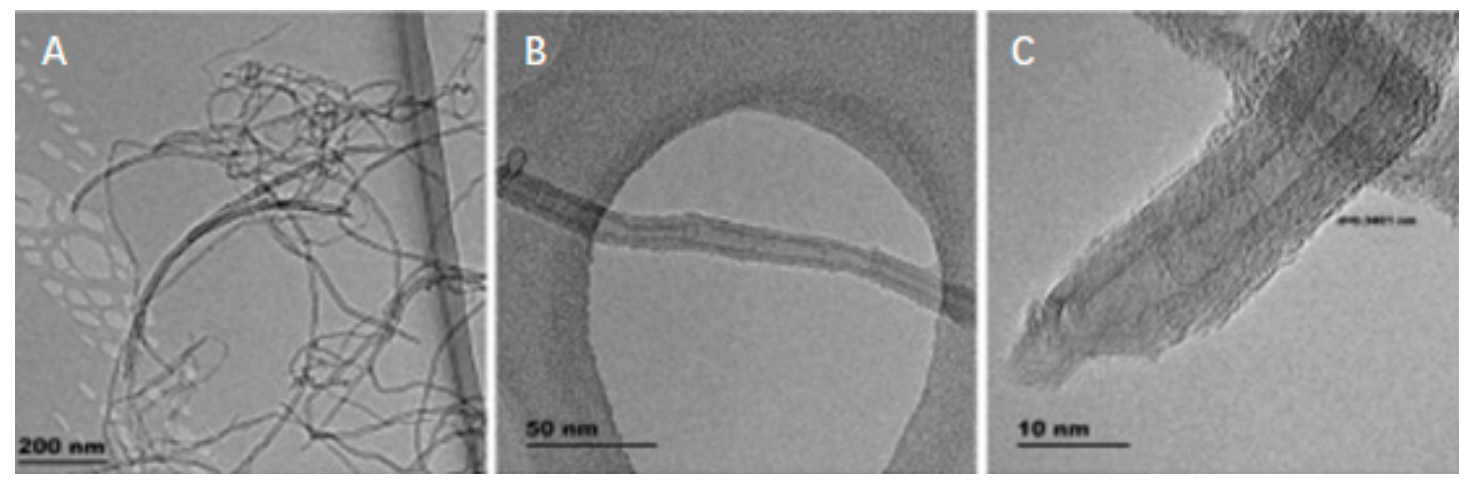

Figure 6. TEM images of multi-walled carbon nanotubes (MWCNTs). (A) agglomerate of MWCNTs; (B) tubular structure of individual MWCNTs; (C) HRTEM image showing the individual walls of MWCNTs [45]. 


\section{Applications of Carbon Nanotubes (CNTs)}

Due to its unique but similar properties, flexibility in chemistry functionalization and biological stability, carbon nanotubes have obtained prominence in recent years and have become a very significant research area particularly for scientists in nanotechnology, materials science, and electronics. CNTs have evolved into one of the most common pure carbon materials due to their strong mechanical stability and properties in electric transport. Carbon nanotubes are essentially cylindrical tubes composed of carbon atoms, which can be functionalized to conduct their particular functions using various techniques. These are used in many uses, such as field emitters with large angular current concentrations, nanoscale bearings, plastic fillers, and even used in semiconductors as component parts. To date, CNTs have been used as nanocarriers in different areas of biomedicine as they have demonstrated strong potential to transcend biological barriers as new delivery systems [46]. Specific substances such as antigen, peptide and nucleic acid may be distributed by highefficiency CNTs to cancer cells, since they are more stable and functional in biological applications relative to other nanomaterials or nanocarriers. In addition, CNTs may also be used in thermal ablation and delivery of drugs, since they can join cells and are independent of the functional group and cell form on the CNT surface [47]. The large surface area of the CNTs may provide several sites for the attachment of specific molecules, allowing flexible derivation [48]. There are also chemically stable CNTs that have the biocompatibility potential with the biological world. This material's actions may be influenced by the degree and form of CNT functionality, as it has features such as high interfacial area with cell membrane that can combine several functionalities [49]. With all these features of CNTs, such as compatibility in biological fluids, these make CNTs a useful tool for diagnosis and therapeutic usage [50].

\subsection{Electronic Devices Using CNTs}

Semiconducting single-wall carbon nanotubes (CNTs) were used in the electronic industries for almost two decades. This is because it has all the required properties to be used in the generation of electronic devices, such as in electrical, chemical, thermal and mechanical applications. It could be shown from one of the very earliest electrical instruments to the latest introduction of the first CNT unit, the CNT field-effect transistors (FETs) [51].

Mechanism used in mobile product production may be complicated. Atomic Force Microscope (AFM) enables nanotubes to be cut into shorter parts using regulated voltages applied to the tips of the Scanning Tunneling Microscope (STM) [52]. This is very useful in the invention of electronic devices as shaping and modifications of nanotubes is possible.

CNTs have been used in many laboratories and factories to build nanodevices and also used to enhance the properties of electronic devices such as metallic wires, sensors, displays and more [53]. It also invents and manufactures nanotube devices that could be useful in circuits of nano-scale, molecular machinery and other nanoelectrical materials [42]. Examples of scientific data indicate that CNTs can bear current at higher densities than metals, rendering CNTs an alternative to metal devices [54]. CNTs can also be used as a Field Effect Transistor (FET) and voltage inverters [55]. In addition, the exterior layers of arc-discharged-made MWNTs may be stripped until the required electronic properties of the outer shell are reached [56]. Blase et al. (1999) have experimented on a related theory and showed that the electronic properties of CNTs inside polymeric materials can be used to achieve desirable electrical applications [42]. Figure 7 shows the application of carbon nanotubes: polymer composites in electronics. 


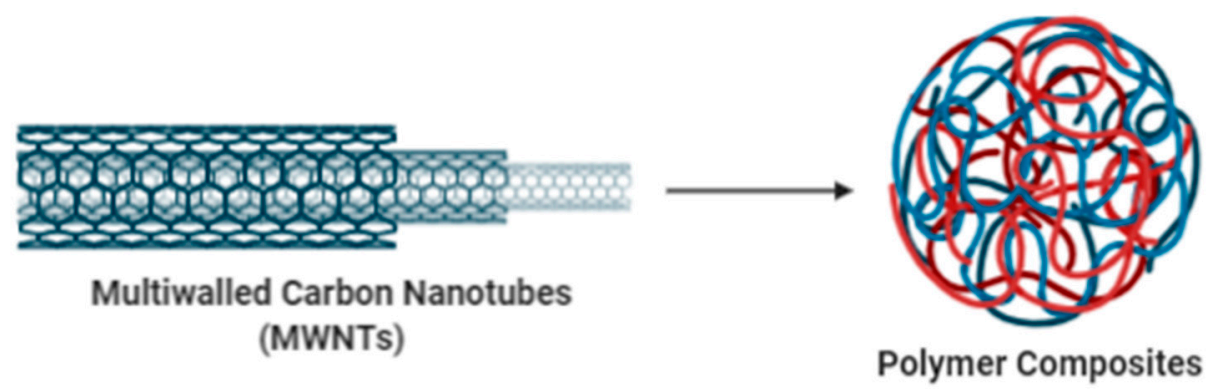

Figure 7. Application of Carbon Nanotubes: Polymer Composites in Electronics.

\subsection{Sensors Using CNTs}

Sensors are essential devices for detecting and are now commonly used in numerous fields, particularly in the biomedical sector. Through adding CNTs onto them, the performance of such biosensors may be improved.

The basic procedure involved is the usage of materials for gas detectors such as vaporsensitive polymers and semiconductor metal oxides [57]. The gas sensing principle is on the gas molecules that adsoroped and desorped on the sensing materials; therefore, the contact between the analytes and the sensing materials will significantly enhance the sensitivity. The critical criteria for efficient and effective gas sensing systems are high sensitivity and selectivity, low analyst usage, quick reaction time and recovery time.

This is demonstrated that specific chemical groups that are bound to the ends of CNTs can be detected utilizing chemical force microscopy techniques. Therefore, different types of sensors can be constructed using composite pellets of nanotube that are gas-sensitive. This may also be used to track leakage in chemical plants, since it is stated that shifts in the resistance rates of CNTs can arise when there is minor shift in the climate. CNTs such as Multi-Walled Carbon Nanotubes (MWNTs) can be used as effective $\mathrm{H}_{2} \mathrm{O}, \mathrm{NH}_{3}, \mathrm{CO}_{2}$ and $\mathrm{CO}$ detectors [56]. Furthermore, by using either SWNTs or MWNTs, fast-responsive and highly sensitive microwave-resonant sensors can be built for detecting NH3 [58]. Other than gas sensing, CNTs can be used as environmentally pressure sensors [42]. It also helps in increasing the speed of biological sensors. Figure 8 shows that the carbon nanotube treated with capture agent (pink) can detect and bind with the blue-colored target protein.

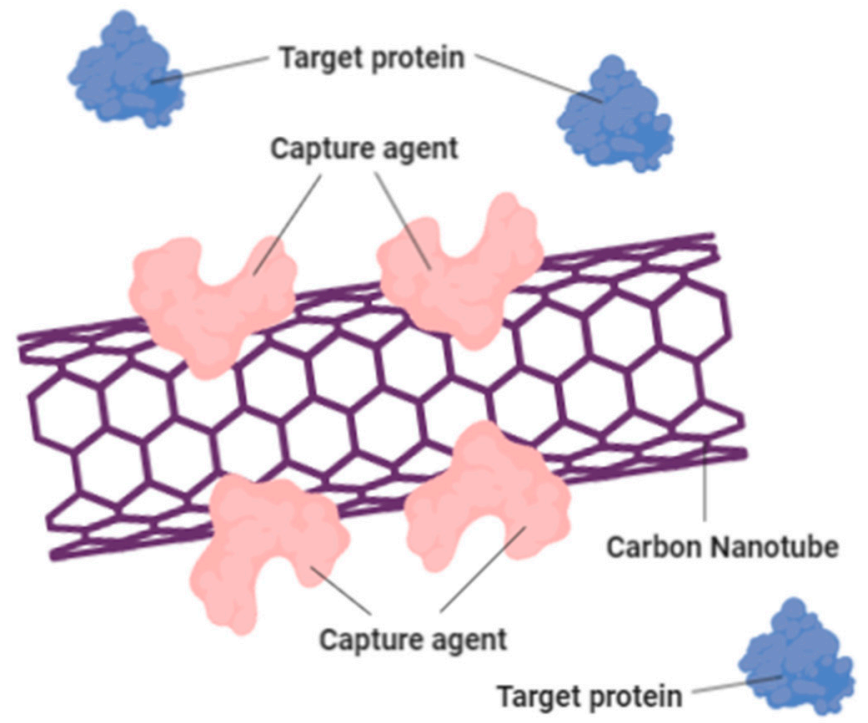

Figure 8. Carbon nanotube treated with capture agent (pink) can detect and bind with the bluecolored target protein. This could change the electrical resistance of the carbon nanotube and creates a sensing device that able to increase the speed of biological sensors. 


\subsection{Medical Applications of CNTs}

The fields related to medical technology such as cancer treatments, gene therapy and other innovative life-threatening disease technologies have shown great improvement and advancement by scientists around the world in recent years. The study of nanomedicine has thus been one of the fastest-growing areas.

The distinctive features and properties of CNTs have inspired scientists to create new nanomedicine technologies. It has been proved that CNTs such as SWNTs and MWNTs have a high potential to serve as more effective alternatives to previous delivery of drugs. Such CNTs will pass through the cell via membranes, carrying pharmaceutical medications, nucleic acids and vaccines to the targets of the substrates. They will increase the drug's solubility and could contribute to greater performance and protection in shipping the desired products to desirable destinations. Therefore, they can act in vivo as perfect nontoxic vessels.

Carbon nanotubes uses in medical sciences, such as in medication and pharmacy, include drug, biomolecule, cell or organ gene transmission, tissue replication, and detection and study of biosensors. Overall, CNTs have demonstrated a very promising future particularly in the medical field [59]. Figure 9 shows the medical applications of carbon nanotubes.

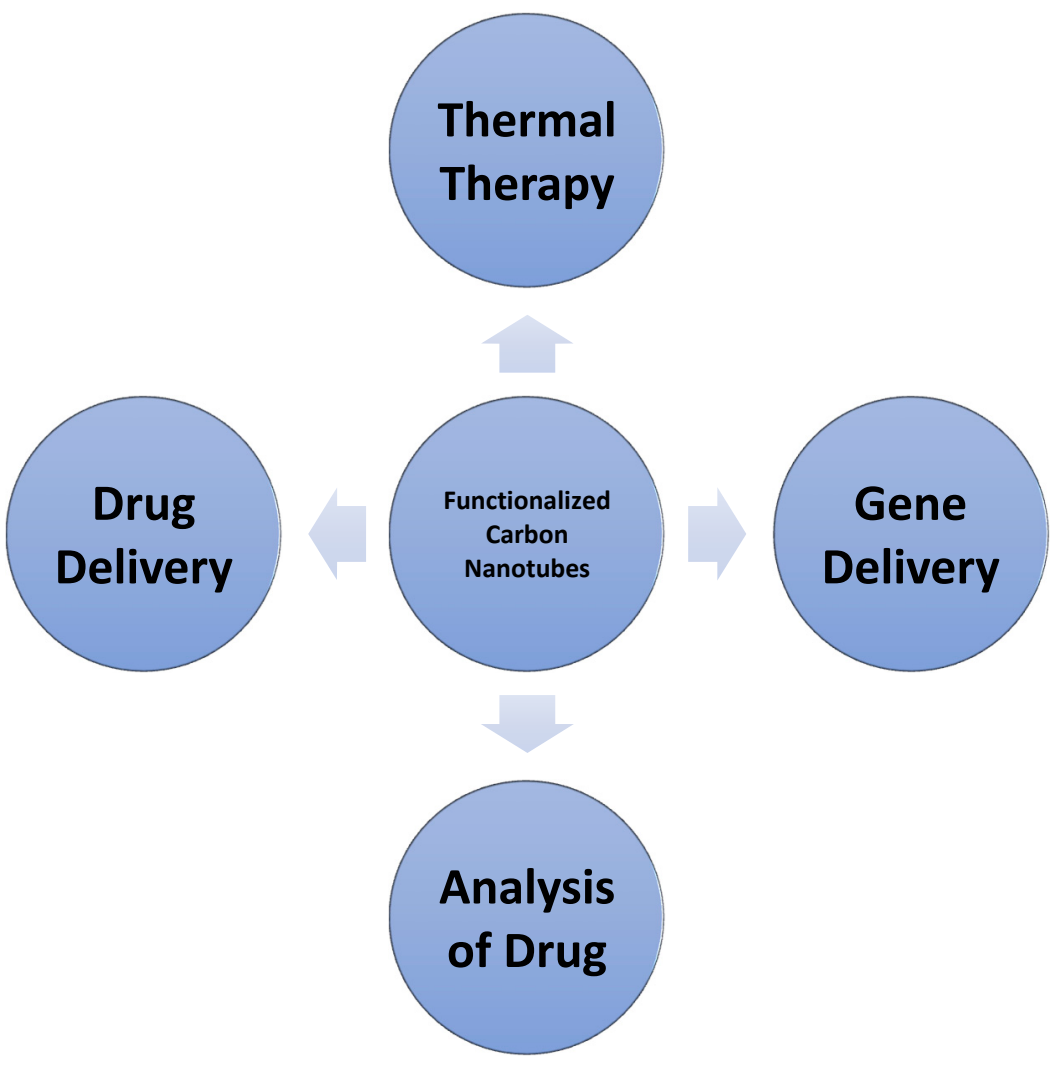

Figure 9. Medical Applications of Carbon Nanotubes.

\subsection{Batteries (Lithium ion Batteries) Using CNTs}

A lithium-ion battery (Li-ion) is an innovative battery system that allows use of lithium ions as a core component in its electrochemistry. It was first commercialized in 1991 and now it is used worldwide for portable devices [60]. Over conventional rechargeable batteries, lithium-ion batteries have many advantages and their production has been very rapid in recent years.

Lithium-ion batteries function in a unique fashion. The positive electrode relinquishes any of the lithium ions that move through the electrolyte to the negative graphite electrode when charging the device. During this process, energy will be taken in by the battery and 
deposited. When the battery is discharged, the lithium ions travel back to the positive electrode through the electrolyte which will produce the battery strength. In all situations, however, electrons move in the opposite direction to the ions along the outer circuit, and energy is used in the process.

Lithium ( $\mathrm{Li}$ ) is a useful element since, due to its low electronegativity, it has unique properties which enable electrons to be easily donated from Li. Therefore, it is one of the main choices for effective battery output. Nevertheless, Li's high reactivity restricts its operability as the metal loses its strength. The incorporation of CNTs into Li in battery manufacturing could address this, as recent work has shown that CNTs should be used in Li ion batteries [54]. One illustration is by inserting Li ions inside CNTs that allows $\mathrm{Li}+$ ions to move from the graphic anode to the cathode, so CNTs may have a large irreversible potential [61]. Calculations were performed to establish the process of charging and discharging in $\mathrm{Li}+$ batteries. It is proposed that the electrochemical strength of these batteries may be improved by chemically or mechanically modifying the surface of the SWNT products. Consequently, other electronics firms have begun to use CNTs as the electrodes in lithium batteries to increase their energy power and service life [62].

\subsection{Carbon Fiber/Multi-Walled Carbon Nanotubes/Epoxy Resin Composite System}

Carbon fibers are fibers which consist of graphene interlocking sheets made up of carbon atoms. Carbon fiber strands are similar to nanotubes, and the fibers are very stiff and have a remarkably high tensile strength. It has been a popular trend lately to incorporate CNTs into the surface of carbon fibers to improve the interfacial properties of composites.

The introduction of multiwall carbon nanotubes (MWCNTS) into the composite carbon fiber (CF)/epoxy resin network is made using basically two methods. The first is to mix CNTs entirely throughout the matrix (matrix modification) and the second method is to attach CNTs (interface modification) to reinforcing fibers. Several methods for injecting CNTs into the fiber surface have been established, such as chemical vapor deposition and chemical grafting [63]. However, for their low cost and convenience, coating fibers with a CNT-containing fitting agent has better benefits [64]. Carbon nanotubes or carbon $(\mathrm{CNT} / \mathrm{C})$ composites are promising for light structures that need a combination of high strength and good conductivity [65]. Such composites have good strength and low degree of thermal expansion and fatigue resistance [66]. Nonetheless, the efficiency of carbon fiberreinforced composites depends on the fiber-matrix interface properties [67]. Carbon fiber (CF) has outstanding technical properties such as high individual strength and hardness, good conductivity and corrosion resistance. CF-reinforced resin matrix composites can be used in a range of applications including turbomachinery, fuel cells and wind turbine applications in automotive power systems [68].

In general, we may infer that by integrating CNTs into CF/polymer composites, hybrid CF/CNTS/polymer composites could be developed which boost the mechanical properties of $\mathrm{CF} /$ polymer composites [69].

\subsection{High-Performance Electromagnetic-Interference Shielding}

Problems of Electromagnetic Interference (EMI) have become a subject of today. This concern can be exacerbated by the widespread usage of computer and networking equipment in manufacturing, the military and trade, which may influence the activity of certain technologies as well as human safety [70]. Carbon nanotubes are very useful in electromagnetic shielding.

Recent work has shown that, due to the synergistic combination of different sources of carbon, a novel 3D nanostructured material consisting of different types of carbon materials through covalent $\mathrm{C}-\mathrm{C}$ bond improves the efficiency of electromagnetic safety [71]. Such special nanostructures of 3D hybrid material, also known as CNT-necklace-like 3D nanostructures, are created by binding CNTs to carbon spheres by covalent $\mathrm{C}-\mathrm{C}$ bonding. Within this structure, the CNTs and carbon spheres or carbon black can function as a separator which effectively inhibits the stacking of individual graphene sheets, resulting in 
significant improvements in electromagnetic shielding efficiency. The carbon spheres are smoothly grown on the 3D CNT hybrid nanostructures which load nickel, which act as a prototype utilizing chemical vapor deposition. These form of carbon spheres possessed magnetic characteristics and these materials have great advantages in electromagnetic interference (EMI) applications over single phase carbon nanomaterials for the electromagnetic shielding effect. The carbon spheres often act as solid welding points in a porous continuous network backbone consisting of well-connected CNTs [72].

By using such carbon nanotubes (CNTs) or graphene chains, foam systems with a porosity of up to $96 \%$ packed with lightweight carbon materials may be produced to achieve strong shielding performance (SE) [73].

\subsection{Fouling Control and Anti-Fouling Mechanism of Polyvinylidene Fluoride Ultrafiltration Membranes}

The use of carbon nanotubes in the production of composite membranes is known, in this case, the ultrafiltration membranes of Polyvinylidene Fluoride. However, CNTs had the dispersion problem for graphene derivatives due to the strong forces [74]. The poor dispersion of carbon nanotubes and graphene into polymeric matrices can also restrict the performance of low-dimensional nanomaterial-based composite membranes. Carbon nanotubes derivatives can be used in fouling the carbon nanomaterials stacking operation. It has been theoretically shown that single-dimensional oxidized carbon nanotubes (OMWCNTs) and two-dimensional graphene oxide (GO) have a synergetic impact on the permeation and anti-fouling efficiency of polyvinylidene fluoride (PVDF) composite membranes. The addition of OMWCNTs will effectively prevent stacking of individual GOs.

OMWCNTs can bridge adjacent to GO, in order to prevent accumulation and enhance the antifouling efficiency of composite membranes. Through integrating the lowdimensional carbon nanomaterials into the membrane matrix, it can improve the water permeability, hydrophilicity and anti-fouling performance of polymer-based nanocomposite membranes. It is understood that they may create a co-supporting network by integrating two nanofillers, such as carbon nanotubes and graphene derivatives, which protects tube fillers from damage and fracture during platelet geometry processing, resulting in improved properties [75]. Thus, by mixing one-dimensional oxidized carbon nanotubes (OMWCNTs) and two-dimensional graphene oxide (GO) resulting in a strong synergistic effect between the two materials, this will result in a superior ultrafiltration membrane with improved anti-fouling performance relative to the membranes modified by either OMWCNTs or GO. Overall, it can be inferred that by reducing the stacking effect and accumulation of low-dimensional carbon nanomaterials, the problems that obstruct future applications for carbon-based composite membranes can be overcome. In this scenario, it can be done by merging OMWCNTs and GO to achieve better efficiency of composite PVDF membranes [76].

\section{Characteristics of Bacterial Flagella in Comparison with Carbon Nanotubes}

Bacterial flagella have been used as components in the manufacturing of nanotubes in recent studies, this is owing to the evidence that bacterial flagella is closely connected to the nanotubes that are currently commonly utilized in factories, the carbon nanotubes. Bacterial flagella's features and properties are fairly similar to carbon nanotubes in such a way that it gives the bacterial flagella the ability to be used as components in the manufacturing of nanotubes, which may often be called bacterial nanotubes. The length of bacterial flagella is around 5 to $20 \mu \mathrm{m}$ [77]. While for carbon nanotubes, specifically the 3 main categories, SWCNTs, DWCNT and MWCNTs, the length are normally around 5 to $30 \mu \mathrm{m}$ [42]. The length of both bacterial flagella and carbon nanotubes are close to each other and therefore there is no issue in using bacterial flagella in the fabrication of nanotubes. However, the length of carbon nanotubes varies depending on the preparation method [42]. It can vary from as small as nanometer $(\mathrm{nm})$ all the way to centimeter $(\mathrm{cm})$ [78]. The production of bacterial nanotubes may therefore be regulated by the period used by the manufacturing 
phase. It is shown that a single bacterial nanotube may stretch within $15 \mathrm{~min}$ to a length of about $15 \mu \mathrm{m}$. After $50 \mathrm{~min}$ it could achieve an average overall length of $40 \mu \mathrm{m}$ and gradually after $70 \mathrm{~min}$ the development of bacterial nanotube achieved a total length of $57 \mu \mathrm{m}$ with a corresponding surface area of $9 \mu \mathrm{m}^{2}$ [79]. Bacterial flagella is known to be a viable alternative for biotemplates due to its unusual natural properties, such as tubular structures of length that could be controlled [27]. This indicated that the bacterial flagella can be manipulated in the fabrication process of bacterial nanotubes to achieve desired lengths just as the length of carbon nanotubes that could be manipulated accordingly by using different methods of preparation.

The diameter of bacterial flagella is around 10 to $30 \mathrm{~nm}$ while for carbon nanotubes, all 3 main categories are different in diameter. For SWCNTs, the diameter is around 1 to 2 $\mathrm{nm}$, for DWCNTs, it is around 2 to $4 \mathrm{~nm}$ and for MWCNTs, the gap is larger as it can vary from 2 to $50 \mathrm{~nm}$. From here, we could deduce that all the diameters involved from bacterial flagella to carbon nanotubes fall in the range of $\mathrm{nm}$. However, in general, the diameter of bacterial flagella is larger than carbon nanotubes. Nonetheless, Single-walled carbon nanotubes (SWCNTs) with large diameters (LDs) greater than $3 \mathrm{~nm}$ are stated to have broad applications. In implementations, it has been shown that LD-SWCNTs demonstrate greater efficiency as a catalyst supply than traditional (small diameter) SD-SWCNTs, MWCNTs and the industrial catalyst. LD-SWCNTs may also find applications in a broad variety of fields, including biomedicine and energy industries [80]. Bacterial flagella have been demonstrated to be promising bio-templates with its unique structural properties and can be exploited to build nanomaterials such as bacterial nanotubes [27]. In this context, bacterial flagella which have bigger diameter than the commercial carbon nanotubes could be an advantage for the fabrication of LD-SWCNTs that are beneficial in a wide range of applications. Jo et al. (2012) reported that by using repolymerized Salmobella typhimurium flagella as a bio-template, a simple hydrolysis and condensation process could facilitate controllable growth of silica nanotubes. Results from the study showed that the thickness of silica-mineralized flagella nanotubes (SMFNs) can be regulated across a broad range by adjusting the structural conditions, including the concentration of tetraethoxysilane (TEOS) and the reaction time. This should be achieved to achieve a thicker coating of silica by increasing the TEOS concentration ratio and the reaction time. The effectively produced SMFNs not only exhibit the intrinsic tubular flagella structure but can also be modified by changing the silica shell thickness to match the required requirements [81]. Figure 10 shows the thickness analysis and SEM images of SMFNs [81]. Figure 11 shows the TEM image of the SMFNs [81]. 

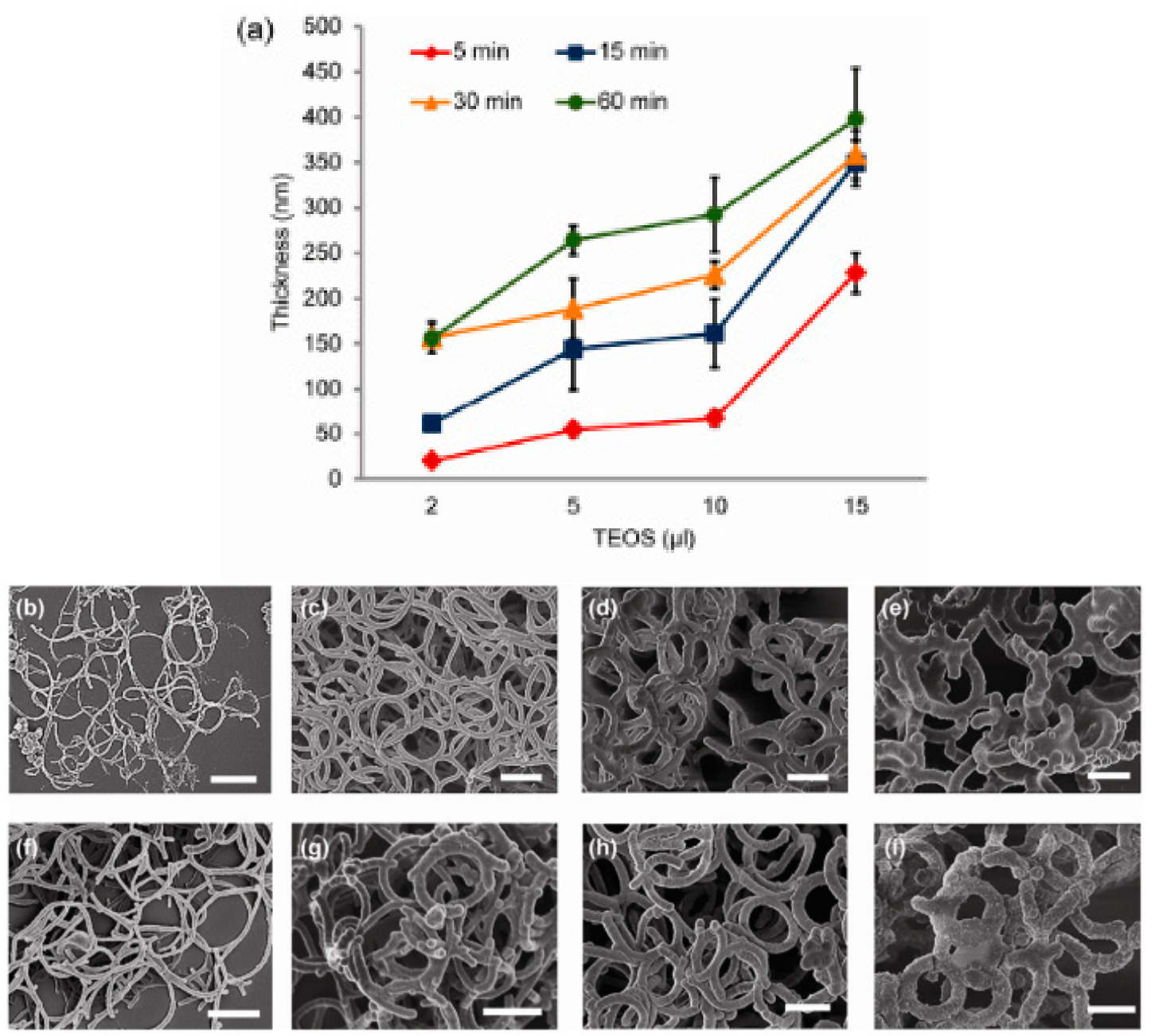

Figure 10. Thickness or diameter of flagella analysis (a) and SEM images of SMFNs generated by the addition of different TEOS concentrations (b) and (e) after 15 min of reaction time; (b) $2 \mu \mathrm{L}$, (c) $5 \mu \mathrm{L}$, (d) $10 \mu \mathrm{L}$, and (e) $15 \mu \mathrm{L}$, and by the different reaction times (f) and (i) at $10 \mu \mathrm{L}$ TEOS; (f) $5 \mathrm{~min},(\mathbf{g}) 15 \mathrm{~min}$, (h) $30 \mathrm{~min}$, and (i) $60 \mathrm{~min}$. The scale bar indicates $1 \mu \mathrm{m}$ [81].

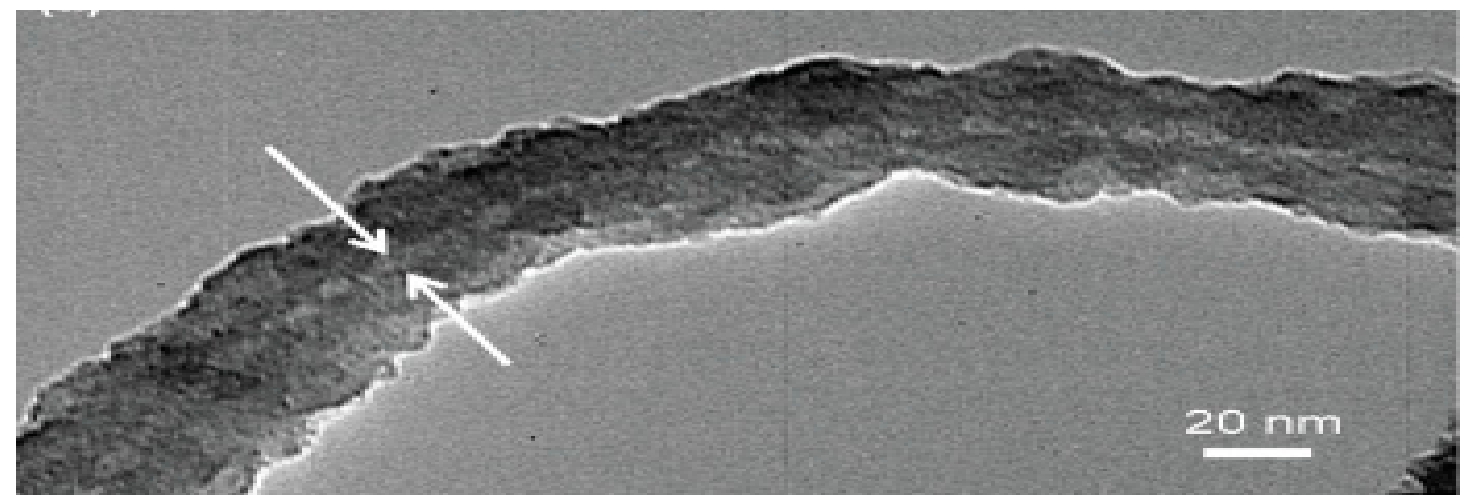

Figure 11. TEM image of the SMFNs, gelation aging time of $15 \mathrm{~min}$, and TEOS $2 \mu \mathrm{L}$, showing the dense silica coating on the external surface of the flagella. The hollow inner channel of the flagellum with uniform diameter was observed as a white line indicating that the synthesized SMFNs retain the natural tubular flagellum structure [81].

The structure of bacteria flagella is called the axial structure which consists of three major parts, the basal body, the hook and the filament [25]. The filament is a hollow tube composed of up to 20,000 subunits of a single flagellin protein [10]. Carbon nanotubes are generally cylindrical in shape with hexagonal lattice helicity. The nanotubes are loops or 
tubes structured in a triangular lattice with dimensions of $\approx 1.7 \mathrm{~nm}$. For DWCNTs and MWCNTs, the tube-tube distance $\approx 0.314 \mathrm{~nm}[82]$. Carbon nanotubes are long and thin hollow fibre-like nanomaterials composed of a single, double or multiple layers of rolled graphene [83]. By comparing both bacterial flagella and carbon nanotubes, both possess hollow core and hence bacterial flagella are suitable to be used as the materials for the fabrication of bacterial nanotubes. Wang et al. (2008) note that because bacterial flagella exists naturally in hollow nanotubes, the resulting hybrid materials are supposed to be double-layered nanotubes that can be used as an alternative to DWCNTs [28].

The bacterial flagellum is a locomotive organelle that includes a membrane-embedded nanomotor that rotates long helical filaments. Flagellar filaments are natural protein nanotubes with an outer diameter of $23 \mathrm{~nm}$, which can raise to $20 \mu \mathrm{m}$ [84]. This indicated that flagellum has extraordinary mechanical properties as it is extremely rigid and has an elastic modulus estimated at around $1010 \mathrm{~N} / \mathrm{m}^{2}$ [85]. Therefore, they possess remarkable durability and stability. The elastic modulus of SWCNTs, DWCNTs and MWCNTs are $~ 1$ $\mathrm{TPa}, \sim 800 \mathrm{GPa}$ and $\sim 0.3-1 \mathrm{TPa}$ respectively $\left(1 \mathrm{TPa}=10^{12} \mathrm{~N} / \mathrm{m}^{2}\right)$. Though it is obvious that CNTs have higher elastic modulus compared to bacterial flagella, however, it is believed that during the fabrication of bacterial nanotubes from bacterial flagella, the modification of bacterial flagella through a series of processes would enhance its elastic modulus. Leung et al. (2011) has characterized bacterial nanotubes made from Shewanella oneidensis and showed that they have enough mechanical strength (elastic modulus $\sim 1 \mathrm{GPa}$ ) to be used as a building block for construction of electronic devices [86]. Bacterial flagella has also been found to have the properties to function as active nanostructures. Through adjusting the helical handling and pitch, they may dynamically respond to the atmosphere in reaction to different external stimuli such as environmental, biological, electrical, mechanical, and optical stimuli; this is called polymorphic transformation. These properties make notable stability and durability of flagellar filaments which enable them to withstand high temperatures (up to $60{ }^{\circ} \mathrm{C}$ ) and extreme $\mathrm{pH}(7 \pm 4)$ [87]. Therefore, all these remarkable characteristics or properties of bacterial flagella gave a significant value to bacterial flagella itself in the fabrication of bacterial nanotubes.

The tensile strength of bacterial flagella is around $3.5 \mathrm{pN} / \mu \mathrm{m}^{2}(\mathrm{~Pa})$ while for SWCNTs, DWCNTs and MWCNTs, the tensile strength is $50-500 \mathrm{GPa}, \sim 30 \mathrm{GPa}$ and $10-50 \mathrm{GPa}$ respectively. Scientists believe that bacterial nanotubes can be developed into instruments that are usable in water and moist environments [88]. To achieve this, the tensile strength of bacterial nanotubes has to be high enough so that it could withstand the water resistance. Tensile strength has a close relation with elastic modulus. Elastic modulus defines a material's elasticity, which is the relation between a material's deformation and the strength used to deform it. Tensile strength is maximum stress valuethat a material can withstand. As it is proven that the elastic modulus of bacterial flagella could be enhanced during the fabrication of bacterial nanotubes, hence, it could also improve the tensile strength of bacterial flagella through a series of processes involved during the fabrication of bacterial nanotubes.

The electrical conductivity of bacteria is around 35 to $350 \mathrm{ohms} / \mathrm{cm}^{3}$ while for CNTs, it is around $10^{6}$ to $10^{7} \mathrm{~S} / \mathrm{m}$. Tan et al. (2016) demonstrated that microbial nanowires can be modified using genetic and protein engineering. Different ligands (metals) can be attached to the microbial nanowires that are able to help in modulating its electric behaviour and eventually, increase its electrical conductivity significantly. In a recent study by Tan et al. (2016) has shown that, by replacing C-terminal phenylalanine and tyrosine of PilA (protein) with tryptophan in Geobacter sulfurreducens microbial nanowires, it could decrease its diameter by half and increase its conductivity by 2000-fold [89]. In this context, Geobacter sulfurreducens microbial nanowires have been modified to have better conductive and adhesive properties. In addition to thorough biochemical and electrical characterization, the detection of new microbial nanowires containing microorganisms that contribute to the development of microbial nanowires is essential. This would help to classify the most appropriate microbial nanowires for different functional applications 
in the bioenergy and potentially biotherapeutics sectors [90]. In another case, Gorby et al. (2006) demonstrated that Shewanella oneidensis MR-1 produces electrically conductive nanowires (a wire made from nanotubes) in response to $\mathrm{O}^{2}$ limitation. In an earlier report, the scanning tunnelling microscope (STM) results confirmed that nanowires produced by MR-1 are efficient electrical conductors [91]. The discovery of bacterial nanowires and the description of the electron transfer components needed for electrical conductivity make important strides in understanding the processes involved in the movement of bacterial nanowires electronically [92]. Table 5 summarizes the characteristics of Bacterial Flagella in Comparison with Carbon Nanotubes.

Table 5. Characteristics of Bacterial Flagella in Comparison with Carbon Nanotubes.

\begin{tabular}{|c|c|c|c|c|c|}
\hline $\begin{array}{c}\text { Charac- } \\
\text { teristics/Attributes }\end{array}$ & $\begin{array}{c}\text { Bacterial Flagella/(as } \\
\text { Nanotubes) }\end{array}$ & $\begin{array}{c}\text { Single-Walled } \\
\text { Carbon Nanotubes }\end{array}$ & $\begin{array}{c}\text { Double-Walled } \\
\text { Carbon Nanotubes }\end{array}$ & $\begin{array}{c}\text { Multi-Walled } \\
\text { Carbon Nanotubes }\end{array}$ & References \\
\hline Length & $5-20 \mu \mathrm{m}$ & $\begin{array}{l}\text { Vary depending on } \\
\text { preparation method. } \\
\text { Normally } 5-30 \mu \mathrm{m} .\end{array}$ & $\begin{array}{l}\text { Vary depending on } \\
\text { preparation method. } \\
\text { Normally } 5-30 \mu \mathrm{m} \text {. }\end{array}$ & $\begin{array}{l}\text { Vary depending on } \\
\text { preparation method. } \\
\text { Normally } 10-30 \mu \mathrm{m} \text {. }\end{array}$ & {$[42,77]$} \\
\hline Diameter & $10-30 \mathrm{~nm}$ & $1-2 \mathrm{~nm}$ & $2-4 \mathrm{~nm}$ & $2-50 \mathrm{~nm}$ & {$[42,77]$} \\
\hline Lattice Structure & $\begin{array}{l}\text { Axial (hollow) } \\
\text { structure consists of } \\
\text { three major parts, the } \\
\text { basal body, the hook } \\
\text { and the filament. }\end{array}$ & \multicolumn{3}{|c|}{$\begin{array}{l}\text { (Cylindrical and hollow) hexagonal lattice helicity } \\
\text { Nanotubes: ropes, tubes arranged in triangular lattice with lattice } \\
\text { parameters of } \mathrm{a} \approx 1.7 \mathrm{~nm} \text { and tube-tube distance } \approx 0.314 \mathrm{~nm} \text { (for } \\
\text { DWCNTs and MWCNTs) }\end{array}$} & {$[25,82]$} \\
\hline Elastic Modulus & $1010 \mathrm{~N} / \mathrm{m}^{2}$ & $\sim 1 \mathrm{TPa}$ & $\sim 800 \mathrm{GPa}$ & $\sim 0.3-1 \mathrm{TPa}$ & {$[82,93]$} \\
\hline Tensile strength & $3.5 \mathrm{pN} / \mu \mathrm{m}^{2}(\mathrm{~Pa})$ & 50-500 GPa & $\sim 30 \mathrm{GPa}$ & 10-50 GPa & {$[82,94,95]$} \\
\hline $\begin{array}{c}\text { Electrical } \\
\text { Conductivity }\end{array}$ & $\begin{array}{c}\text { 35-350 ohms } / \mathrm{cm}^{3} \\
\text { (bacteria) }\end{array}$ & \multicolumn{3}{|c|}{$10^{6}$ to $10^{7} \mathrm{~s} / \mathrm{m}$} & {$[96,97]$} \\
\hline
\end{tabular}

\section{Advantages of Bacterial Flagella as Nanotubes in Comparison with Carbon Nanotubes}

Bacterial flagella have been highly suggested by researchers in this field to be used as an alternative to carbon nanotubes in many fields. From the discussion as above, it is believed that bacterial flagella have advantages over carbon nanotubes in some extents. In short, we can conclude that both bacterial flagellum and carbon nanotube are basically hollow tube with certain lengths. Their characteristics in terms of structure, elastic modulus, tensile strength and electrical conductivity are highly relatable to each other as well. Therefore, bacterial flagella are said to be suitable for the fabrication of bacterial nanotubes that act as an alternative to carbon nanotubes. Table 6 summarizes the advantages of bacterial flagella as nanotubes in comparison with carbon nanotubes.

Table 6. Advantages of Bacterial Flagella as Nanotubes in Comparison with Carbon Nanotubes.

\begin{tabular}{cccc}
\hline Bacterial Flagella as Nanotubes & Reference & Carbon Nanotubes & Reference \\
\hline $\begin{array}{c}\text { The capability to mass produce } \\
\text { biomaterials of uniform size, cheaper } \\
\text { production cost }\end{array}$ & {$[27]$} & $\begin{array}{c}\text { The production is } \\
\text { relatively expensive. }\end{array}$ & {$[98]$} \\
\hline $\begin{array}{c}\text { Precise structure and lower cost of } \\
\text { production, therefore, lower cost in } \\
\text { implementing the technology. }\end{array}$ & [27] & $\begin{array}{c}\text { Expensive to } \\
\text { implement this new } \\
\text { technology in } \\
\text { replacing the } \\
\text { previous technology. } \\
\text { Most researchers do } \\
\text { not understand how } \\
\text { CNTs work. }\end{array}$ & [98] \\
\hline Environmentally Friendly. & [27] & Environmental Risk. \\
\hline
\end{tabular}




\section{Concluding Remarks}

This review article has thoroughly discussed on the types and applications of bacterial flagellum and carbon nanotubes. It also critically reviewed on the characteristics of bacterial flagellum in comparison with carbon nanotubes and subsequently, described on the advantages of bacterial flagellum as nanotubes in comparison with carbon nanotubes. Overall, bacterial flagella and carbon nanotubes possess huge potential in the field of nanotechnology. However, bacterial flagella are a very promising alternative to replace carbon nanotubes in various field. This can be seen from the aspect of the characteristics of bacterial flagella which are comparable to carbon nanotubes, from length, diameter, structure, elastic modulus, tensile strength to electrical conductivity. In addition, bacterial flagella are also more environmentally friendly and lower cost of production as compared to carbon nanotubes. Therefore, as a concluding remark, bacterial flagella has a huge potential to be used as a substance in the fabrication of nanotubes, namely, the bacterial nanotubes. Nevertheless, further researches should still be carried out to study deeper on bacterial flagella so that it can be a promising alternative to carbon nanotubes and its applications could benefits mankind as well as the environment.

Author Contributions: Conceptualization, C.N.W.C., H.A.T., N.I., B.A., M.M.Z.M. and L.K.Y.; writing-original draft preparation, C.N.W.C.; writing-review and editing, C.N.W.C. and H.A.T.; funding acquisition, H.A.T. and N.I. All authors have read and agreed to the published version of the manuscript.

Funding: This research was funded by Malaysia Ministry of Higher Education (MOHE) with grant number 203.PTEKIND.6711701.

Acknowledgments: I would like to thank the funding source of this project which is Malaysia Ministry of Higher Education (MOHE) with grant number 203.PTEKIND.6711701 (FRGS Grant) that titled Reinforcement Mechanism of Sago Starch Films by Bacteria. I would also like to thank Universiti Sains Malaysia for the scholarship under USM Fellowship Scheme that sponsor me throughout my Master's degree.

Conflicts of Interest: The authors declared that there is no conflict of interest.

Copyright and Permissions: Figure 2: Ferooz and Lettesson, 2010. This article is published under license to BioMed Central Ltd. This is an Open Access article which is distributed under the terms of the Creative Commons Attribution 2.0 International License (https: / / creativecommons.org/licenses / by (2.0), which permits unrestricted use, distribution, and reproduction in any medium, provided the original work is properly cited. Figure 4: Nguyen et al., 2012. This is an Open Access article which is distributed under the terms of the Creative Commons Attribution 3.0 International License ( https://creativecommons.org/licenses/by/3.0/), which permits copy and redistribute the material in any medium or format and also remix, transform, and build upon the material for any purpose, even commercially. Any further distribution of this work must maintain attribution to the author(s) and the title of the work, journal citation and DOI which has been done accordingly. License: https:// creativecommons.org/licenses/by /3.0/legalcode. Figure 5: Bacsa et al., 2003. This is an Open Access article which is distributed under the terms of the Creative Commons Attribution 3.0 International License (https:/ / creativecommons.org/licenses/by/3.0/), which permits copy and redistribute the material in any medium or format and also remix, transform, and build upon the material for any purpose, even commercially. Any further distribution of this work must maintain attribution to the author(s) and the title of the work, journal citation and DOI which has been done accordingly. License: https: / / creativecommons.org/licenses/by/3.0/legalcode. Figure 6: Lephuting et al., 2018. This is an Open Access article which is distributed under the terms of the Creative Commons Attribution 3.0 International License (https:// creativecommons.org/licenses/by/3.0/), which permits copy and redistribute the material in any medium or format and also remix, transform, and build upon the material for any purpose, even commercially. Any further distribution of this work must maintain attribution to the author(s) and the title of the work, journal citation and DOI which has been done accordingly. License: https:// creativecommons.org/licenses/by/3.0/legalcode. Figures 10 and 11: Jo et al. (2008). This is an Open Access article which is distributed under the terms of the Creative Commons Attribution 3.0 International License (https:/ / creativecommons.org/licenses/by/3.0/), which permits copy and redistribute the material in any medium or format and also remix, transform, and build upon the material for any purpose, even commercially. Any further distribution of this work must maintain attribution to the author(s) and the title of the work, journal citation and DOI which has been done accordingly. License: https://creativecommons.org/licenses/by/3.0/legalcode. 


\section{References}

1. Ho, B.K.X.; Azahari, B.; Yhaya, M.F.B.; Talebi, A.; Ng, C.W.C.; Tajarudin, H.A.; Ismail, N. Green technology approach for reinforcement of calcium chloride cured sodium alginate films by isolated bacteria from palm oil mill effluent (Pome). Sustainability 2020, 12, 9468. [CrossRef]

2. Ng, C.W.C.; Ismail, A.F.; Makhtar, M.M.Z.; Jamaluddin, M.N.F.; Tajarudin, H.A. Conversion of food waste via two-stage fermentation to controllable chicken feed nutrients by local isolated microorganism. Int. J. Recycl. Org. Waste Agric. 2020, 9, 33-47. [CrossRef]

3. Mohd, Z.M.M.; Tajarudin, H.A. Electricity generation using membrane-less microbial fuel cell powered by sludge supplemented with lignocellulosic waste. Int. J. Energy Res. 2020, 44, 3260-3265. [CrossRef]

4. Othman, M.F.; Tamat, M.R.; Wan Nadiah, W.A.; Serri, N.A.; Aziz, H.A.; Tajarudin, H.A. Bioconversion of leachate to acetic and butyric acid by Clostridium butyricum NCIMB 7423 in membrane fermentor. Pertanika J. Sci. Technol. 2017, 25, 39-48.

5. Aziz, H.A.; Tajarudin, H.A.; Wei, T.H.L.; Alazaiza, M.Y.D. Iron and manganese removal from groundwater using limestone filter with iron-oxidized bacteria. Int. J. Environ. Sci. Technol. 2020, 17, 2667-2680. [CrossRef]

6. Terashima, H.; Kojima, S.; Homma, M. Chapter 2 Flagellar Motility in Bacteria. Structure and Function of Flagellar Motor; Elsevier Inc.: Amsterdam, The Netherlands, 2008; Volume 270, ISBN 9780123745835.

7. Westerlund-Wikström, B. Peptide display on bacterial flagella: Principles and applications. Int. J. Med. Microbiol. 2000, 290, 223-230. [CrossRef]

8. Lamberti, M.; Pedata, P.; Sannolo, N.; Porto, S.; De Rosa, A.; Caraglia, M. Carbon nanotubes: Properties, biomedical applications, advantages and risks in patients and occupationally-exposed workers. Int. J. Immunopathol. Pharmacol. 2015, 28, 4-13. [CrossRef]

9. Haiko, J.; Westerlund-wikström, B. The Role of the Bacterial Flagellum in Adhesion and Virulence. Biology 2013, 1242-1267. [CrossRef]

10. Van Gerven, N. Pili and Flagella: Biology, Structure, and Biotechnological Applications I. Introduction; Academic Press: Cambridge, MA, USA, 2011; Volume 103, ISBN 9780124159068.

11. Fiedler, T.; Köller, T.; Kreikemeyer, B. Streptococcus pyogenes biofilms-Formation, biology, and clinical relevance. Front. Cell. Infect. Microbiol. 2015, 5, 15. [CrossRef]

12. Subramanian, S.; Kearns, D.B. Functional Regulators of Bacterial Flagella. Annu. Rev. Microbiol. 2019, 73, 225-246. [CrossRef]

13. Nakamura, S.; Minamino, T. Flagella-Driven Motility of Bacteria. Biomolecules 2019, 9, 279. [CrossRef] [PubMed]

14. Kalmokoff, M.L.; Jarrell, K.F.; Koval, S.F. Isolation of flagella from the archaebacterium Methanococcus voltae by phase separation with Triton X-114. J. Bacteriol. 1988, 170, 1752-1758. [CrossRef] [PubMed]

15. Echazarreta, M.A.; Klose, K.E. Vibrio Flagellar Synthesis. Front. Cell. Infect. Microbiol. 2019, 9, 131. [CrossRef] [PubMed]

16. Morimoto, Y.V.; Minamino, T. Structure and Function of the Bi-Directional Bacterial Flagellar Motor. Biomolecules 2014, 4, 217-234. [CrossRef] [PubMed]

17. Schuhmacher, J.S.; Thormann, K.M.; Bange, G. How bacteria maintain location and number of flagella? FEMS Microbiol. Rev. 2015, 39, 812-822. [CrossRef]

18. Evans, L.D.B.; Hughes, C.; Fraser, G.M. Building a flagellum outside the bacterial cell. Trends Microbiol. 2014, $22,566-572$. [CrossRef]

19. Ferooz, J.; Letesson, J.J. Morphological analysis of the sheathed flagellum of Brucella melitensis. BMC Res. Notes 2010, 3 , 33320102010. [CrossRef]

20. Iwazawa, J.; Imae, Y.; Kobayasi, S. Study of the torque of the bacterial flagellar motor using a rotating electric field. Biophys. J. 1959, 64, 925-933. [CrossRef]

21. Mora, T.; Yu, H.; Sowa, Y.; Wingreen, N.S. Steps in the Bacterial Flagellar Motor. PLoS Comput. Biol. 2009, 5. [CrossRef]

22. Nirody, J.A.; Berry, R.M.; Oster, G. The Limiting Speed of the Bacterial Flagellar Motor. Biophys. J. 2016, 111, 557-564. [CrossRef]

23. Lele, P.P.; Hosu, B.G.; Berg, H.C. Dynamics of mechanosensing in the bacterial fl agellar motor. Proc. Natl. Acad. Sci. USA 2013, 110, 11839-11844. [CrossRef] [PubMed]

24. Guttenplan, S.B.; Shaw, S.; Kearns, D.B. The cell biology of peritrichous flagella in Bacillus subtilis. Mol. Microbiol. 2013, 87, 211-229. [CrossRef] [PubMed]

25. Imada, K. Bacterial flagellar axial structure and its construction. Biophys. Rev. 2018, 10, 559-570. [CrossRef] [PubMed]

26. Selvakumar, R.; Seethalakshmi, N.; Thavamani, P.; Naidu, R.; Megharaj, M. Recent advances in the synthesis of inorganic nano/microstructures using microbial biotemplates and their applications. RSC Adv. 2014, 4, 52156-52169. [CrossRef]

27. Jo, W.; Cheang, U.K.; Kim, M.J. Development of flagella bio-templated nanomaterials for electronics. Nano Converg. 2014, 1, 1-14. [CrossRef]

28. Wang, F.; Li, D.; Mao, C. Genetically modifiable flagella as templates for silica fibers: From hybrid nanotubes to 1D periodic nanohole arrays. Adv. Funct. Mater. 2008, 18, 4007-4013. [CrossRef]

29. Vijayan, V.; Parasuraman, M.S.; Vasanthraj, S.; Varadharajan, R. Nanoswimmers-a Advance Tool for Medical Application. Rapp. Pharm. 2015, 1, 118-121.

30. Ali, J.; Cheang, U.K.; Darvish, A.; Kim, H.; Kim, M.J. Biotemplated flagellar nanoswimmers. APL Mater. 2017, 5. [CrossRef]

31. Weber, M.; Julbe, A.; Ayral, A.; Miele, P.; Bechelany, M. Atomic Layer Deposition for Membranes: Basics, Challenges, and Opportunities. Chem. Mater. 2018, 30, 7368-7390. [CrossRef] 
32. Li, D.; Zhu, Y.; Yang, T.; Yang, M.; Mao, C. Bacterial flagella as an osteogenic differentiation nano-promoter. Nanoscale Horiz. 2019, 4, 1286-1292. [CrossRef]

33. Kim, J.W.; Tung, S. Bio-hybrid micro/nanodevices powered by flagellar motor: Challenges and strategies. Front. Bioeng. Biotechnol. 2015, 3, 1-8. [CrossRef]

34. Mahltig, B.; Pastore, C. Mineral. and Ceramic Fibers; Elsevier Ltd.: Amsterdam, The Netherlands, 2018; ISBN 9780081022283.

35. Mihai, M.M.; Holban, A.M.; Călugăreanu, A.; Orzan, O.A. Recent advances in diagnosis and therapy of skin cancers through nanotechnological approaches. Nanostruct. Cancer Ther. 2017, 285-305. [CrossRef]

36. Khan, I.; Saeed, K.; Khan, I. Nanoparticles: Properties, applications and toxicities. Arab. J. Chem. 2019, 12, 908-931. [CrossRef]

37. Dubey, G.P.; Ben-Yehuda, S. Intercellular nanotubes mediate bacterial communication. Cell 2011, 144, 590-600. [CrossRef] [PubMed]

38. Hesse, W.R.; Luo, L.; Zhang, G.; Mulero, R.; Cho, J.; Kim, M.J. Mineralization of flagella for nanotube formation. Mater. Sci. Eng. C 2009, 29, 2282-2286. [CrossRef]

39. Li, D.; Qu, X.; Newton, S.M.C.; Klebba, P.E.; Mao, C. Morphology-controlled synthesis of silica nanotubes through pH- and sequence-responsive morphological change of bacterial flagellar biotemplates. J. Mater. Chem. 2012, 22, 15702-15709. [CrossRef] [PubMed]

40. Wu, X.; Ruan, J.; Ohsuna, T.; Terasaki, O.; Che, S. A novel route for synthesizing silica nanotubes with chiral mesoporous wall structures. Chem. Mater. 2007, 19, 1577-1583. [CrossRef]

41. Hwei Leong, O.N.G.; Constanto-Poulos, K.T.; Ginic-Markovic, M.; Clarke, S. Study into the attachment of small and large silanes to carbon nanotube via click chemistry. Polym. Sci. 2019, 5, 2-4. [CrossRef]

42. Ibrahim, K.S. Carbon nanotubes-properties and applications: A review. Carbon Lett. 2013, 14, 131-144. [CrossRef]

43. Nguyen, B.T.; Than, X.T.; Nguyen, V.C.; Tam Ngo, T.T.; Bui, H.T.; Nguyen, X.N.; Phan, H.K.; Phan, N.M. Fabrication of horizontally aligned ultra-long single-walled carbon nanotubes on Si substrates using the fast-heating chemical vapor deposition method. Adv. Nat. Sci. Nanosci. Nanotechnol. 2012, 3. [CrossRef]

44. Bacsa, R.R.; Flahaut, E.; Laurent, C.; Peigney, A.; Aloni, S.; Puech, P.; Bacsa, W.S. Narrow diameter double-wall carbon nanotubes: Synthesis, electron microscopy and inelastic light scattering. New J. Phys. 2003, 5. [CrossRef]

45. Lephuthing, S.S.; Okoro, A.M.; Lesufi, M.; Ige, O.O.; Olubambi, P.A. Effect of milling parameters on the dispersion characteristics of multi-walled carbon nanotubes in transition metal oxides. IOP Conf. Ser. Mater. Sci. Eng. 2018, 430. [CrossRef]

46. Chen, Z.; Zhang, A.; Wang, X.; Zhu, J.; Fan, Y.; Yu, H.; Yang, Z. The Advances of Carbon Nanotubes in Cancer Diagnostics and Therapeutics. J. Nanomater. 2017, 2017. [CrossRef]

47. Utreja, P.; Jain, S.; Tiwary, K.A. Novel Drug Delivery Systems for Sustained and Targeted Delivery of Anti-Cancer Drugs: Current Status and Future Prospects. Curr. Drug Deliv. 2010, 7, 152-161. [CrossRef] [PubMed]

48. Kostarelos, K.; Lacerda, L.; Pastorin, G.; Wu, W.; Wieckowski, S.; Luangsivilay, J.; Godefroy, S.; Pantarotto, D.; Briand, J.P.; Muller, S.; et al. Cellular uptake of functionalized carbon nanotubes is independent of functional group and cell type. Nat. Nanotechnol. 2007, 2, 108-113. [CrossRef] [PubMed]

49. Singh, R.; Pantarotto, D.; Lacerda, L.; Pastorin, G.; Klumpp, C.; Prato, M.; Bianco, A.; Kostarelos, K. Tissue biodistribution and blood clearance rates of intravenously administered carbon nanotube radiotracers. Proc. Natl. Acad. Sci. USA 2006, 103, 3357-3362. [CrossRef]

50. Faria, P.C.B.D.; Santos, L.I.D.; Coelho, J.P.; Ribeiro, H.B.; Pimenta, M.A.; Ladeira, L.O.; Gomes, D.A.; Furtado, C.A.; Gazzinelli, R.T. Oxidized multiwalled carbon nanotubes as antigen delivery system to promote superior CD8+ T Cell response and protection against Cancer. Nano Lett. 2014, 14, 5458-5470. [CrossRef]

51. Shulaker, M.M.; Hills, G.; Patil, N.; Wei, H.; Chen, H.Y.; Wong, H.S.P.; Mitra, S. Carbon nanotube computer. Nature 2013, 501, 526-530. [CrossRef]

52. Postma, H.W.; de Jonge, M.; Yao, Z.; Dekker, C. Electrical transport through carbon nanotube junctions created by mechanical manipulation. Phys. Rev. B Condens. Matter Mater. Phys. 2000, 62, R10653-R10656. [CrossRef]

53. Anantram, M.P.; Léonard, F. Physics of carbon nanotube electronic devices. Rep. Prog. Phys. 2006, 69, 507-561. [CrossRef]

54. Frackowiak, E.; Béguin, F. Electrochemical storage of energy in carbon nanotubes and nanostructured carbons. Carbon 2002, 40, 1775-1787. [CrossRef]

55. Derycke, V.; Martel, R.; Appenzeller, J.; Avouris, P. Carbon Nanotube Inter- and Intramolecular Logic Gates. Nano Lett. 2001, 1, 453-456. [CrossRef]

56. Collins, P.G.; Arnold, M.S.; Avouris, P. Engineering carbon nanotubes and nanotube circuits using electrical breakdown. Science 2001, 292, 706-709. [CrossRef] [PubMed]

57. Yeow, J.T.W.; Wang, Y. A review of carbon nanotubes-based gas sensors. J. Sensors 2009, 2009. [CrossRef]

58. Hahm, M.-G.; Hashim, D.P.; Vajtai, R.; Ajayan, P.M. A review: Controlled synthesis of vertically aligned carbon nanotubes. Carbon Lett. 2011, 12, 185-193. [CrossRef]

59. Durairaj, A.; Basak, S. Carbon Nanotubes (CNTs) Production, Characterisation and Its Applications. Int. J. Adv. Pharm. Sci. 2010, 1, 187-195. [CrossRef]

60. Megahed, S.; Scrosati, B. Lithium-ion rechargeable batteries. J. Power Sources 1994, 51, 79-104. [CrossRef]

61. Lithium-ion, M.; Evanoff, K.; Benson, J.; Schauer, M.; Kovalenko, I.; Lashmore, D.; Ready, W.J. Ultra Strong Silicon-Coated Carbon Nanotube Nonwoven Fabric as a Battery Anode. ACS Nano 2012, 9837-9845. 
62. Meunier, V.; Kephart, J.; Roland, C.; Bernholc, J. Ab Initio Investigations of Lithium Diffusion in Carbon Nanotube Systems. Phys. Rev. Lett. 2002, 88, 420022002. [CrossRef]

63. Fouda, H.; Guo, L. The Mechanical Properties of CF/Epoxy Resin Composite with Adding Different Types of CNTS. Int. J. Eng. Res. Technol. 2017, 6, 311-315.

64. Fouda, H.; Guo, L.; Yue, Y.; Chen, K.; Elsharkawy, K. Synthesis and Characterization of Hybrid CF/MWCNTS/Epoxy Resin Composite System. IOP Conf. Ser. Mater. Sci. Eng. 2017, 220. [CrossRef]

65. Zhang, S.; Hao, A.; Nguyen, N.; Oluwalowo, A.; Liu, Z.; Dessureault, Y.; Park, J.G.; Liang, R. Carbon nanotube/carbon composite fiber with improved strength and electrical conductivity via interface engineering. Carbon 2019, 144, 628-638. [CrossRef]

66. Zhao, Z.; Teng, K.; Li, N.; Li, X.; Xu, Z.; Chen, L.; Niu, J.; Fu, H.; Zhao, L.; Liu, Y. Mechanical, thermal and interfacial performances of carbon fiber reinforced composites flavored by carbon nanotube in matrix/interface. Compos. Struct. 2017, 159, 761-772. [CrossRef]

67. Zhang, X.; Fan, X.; Yan, C.; Li, H.; Zhu, Y.; Li, X.; Yu, L. Interfacial Microstructure and Properties of Carbon Fiber Composites Modified with Graphene Oxide. ACS Appl. Mater. Interfaces 2012, 4, 1543-1552. [CrossRef] [PubMed]

68. De Paiva, J.M.F.; De Nadai Dos Santos, A.; Rezende, M.C. Mechanical and morphological characterizations of carbon fiber fabric reinforced epoxy composites used in aeronautical field. Mater. Res. 2009, 12, 367-374. [CrossRef]

69. Rawal, S.; Brantley, J.; Karabudak, N. Development of Carbon Nanotube-Based Composite for Spacecraft Components; IEEE: Piscataway Township, NJ, USA, 2013; ISBN 978-1-4673-6395-2.

70. Singh, A.P.; Garg, P.; Alam, F.; Singh, K.; Mathur, R.B.; Tandon, R.P.; Chandra, A.; Dhawan, S.K. Phenolic resin-based composite sheets filled with mixtures of reduced graphene oxide, $\gamma-\mathrm{Fe}_{2} \mathrm{O}_{3}$ and carbon fibers for excellent electromagnetic interference shielding in the X-band. Carbon 2012, 50, 3868-3875. [CrossRef]

71. Zhang, Q.; Wang, Y.; Zhang, B.; Zhao, K.; He, P.; Huang, B. 3D superelastic graphene aerogel-nanosheet hybrid hierarchical nanostructures as high-performance supercapacitor electrodes. Carbon 2018, 127, 449-458. [CrossRef]

72. Wang, H.; Li, N.; Wang, W.; Shi, J.; Xu, Z.; Liu, L.; Hu, Y.; Jing, M.; Liu, L.; Zhang, X. Bead nano-necklace spheres on 3D carbon nanotube scaffolds for high-performance electromagnetic-interference shielding. Chem. Eng. J. 2019, 360, 1241-1246. [CrossRef]

73. Zhan, Y.; Wang, J.; Zhang, K.; Li, Y.; Meng, Y.; Yan, N.; Wei, W.; Peng, F.; Xia, H. Fabrication of a flexible electromagnetic interference shielding $\mathrm{Fe}_{3} \mathrm{O}_{4} @$ reduced graphene oxide/natural rubber composite with segregated network. Chem. Eng. J. 2018, 344, 184-193. [CrossRef]

74. Wang, S.; Liang, R.; Wang, B.; Zhang, C. Dispersion and thermal conductivity of carbon nanotube composites. Carbon 2009, 47, 53-57. [CrossRef]

75. Chatterjee, S.; Nafezarefi, F.; Tai, N.H.; Schlagenhauf, L.; Nüesch, F.A.; Chu, B.T.T. Size and synergy effects of nanofiller hybrids including graphene nanoplatelets and carbon nanotubes in mechanical properties of epoxy composites. Carbon 2012, 50, 5380-5386 [CrossRef]

76. Zhang, J.; Xu, Z.; Shan, M.; Zhou, B.; Li, Y.; Li, B.; Niu, J.; Qian, X. Synergetic effects of oxidized carbon nanotubes and graphene oxide on fouling control and anti-fouling mechanism of polyvinylidene fluoride ultrafiltration membranes. J. Memb. Sci. 2013, 448, 81-92. [CrossRef]

77. Biology, B.; Microbes, O. Basic Biology of Oral Microbes. Atlas Oral Microbiol. 2015, 1-14. [CrossRef]

78. Iii, R.; Catalyzed, C.; An, P.; Pyrene-, O.S.; Hu, J.; Zhang, D.; Harris, F.W. Supporting Information for: Growth of Half-Meter Long Carbon Nanotubes Based on Schulz-Flory Distribution. J. Chem. Theory Comput. 2008, 1-13. [CrossRef]

79. Dubey, G.P.; Malli Mohan, G.B.; Dubrovsky, A.; Amen, T.; Tsipshtein, S.; Rouvinski, A.; Rosenberg, A.; Kaganovich, D.; Sherman, E.; Medalia, O.; et al. Architecture and Characteristics of Bacterial Nanotubes. Dev. Cell 2016, 36, 453-461. [CrossRef]

80. Ma, J.; Wang, J.N.; Wang, X.X. Large-diameter and water-dispersible single-walled carbon nanotubes: Synthesis, characterization and applications. J. Mater. Chem. 2009, 19, 3033-3041. [CrossRef]

81. Jo, W.; Freedman, K.J.; Yi, D.K.; Kim, M.J. Fabrication of tunable silica-mineralized nanotubes using flagella as bio-templates. Nanotechnology 2012, 23. [CrossRef]

82. Hasnain, M.S.; Nayak, A.K. Functionalization of carbon nanotubes. SpringerBriefs Appl. Sci. Technol. 2019, 21-28. [CrossRef]

83. Jackson, P.; Jacobsen, N.R.; Baun, A.; Birkedal, R.; Kühnel, D.; Jensen, K.A.; Vogel, U.; Wallin, H. Bioaccumulation and ecotoxicity of carbon nanotubes. Chem. Cent. J. 2013, 7, 1-21. [CrossRef]

84. Klein, Á.; Kovács, M.; Muskotál, A.; Jankovics, H.; Tóth, B.; Pósfai, M.; Vonderviszt, F. Nanobody-Displaying Flagellar Nanotubes. Sci. Rep. 2018, 8, 1-9. [CrossRef]

85. Atsumi, T. An ultrasonic motor model for bacterial flagellar motors. J. Theor. Biol. 2001, 213, 31-51. [CrossRef]

86. Leung, K.M.; Wanger, G.; Guo, Q.; Gorby, Y.; Southam, G.; Lau, W.M.; Yang, J. Bacterial nanowires: Conductive as silicon, soft as polymer. Soft Matter 2011, 7, 6617-6621. [CrossRef]

87. Yamashita, L.; Hasegawa, K.; Suzuki, H.; Vonderviszt, F.; Mimori-Kiyosue, Y.; Namba, K. Structure and switching of bacterial flagellar filaments studied by X-ray fiber diffraction. Nat. Struct. Biol. 1998, 5, 125-132. [CrossRef]

88. Lovley, D.R.; Walker, D.J.F. Geobacter Protein Nanowires. Front. Microbiol. 2019, 10. [CrossRef]

89. Tan, Y.; Adhikari, R.Y.; Malvankar, N.S.; Pi, S.; Ward, J.E.; Woodard, T.L.; Nevin, K.P.; Xia, Q.; Tuominen, M.T.; Lovley, D.R. Synthetic Biological Protein Nanowires with High Conductivity. Small 2016, 12, 4481-4485. [CrossRef]

90. Sure, S.; Ackland, M.L.; Torriero, A.A.J.; Adholeya, A.; Kochar, M. Microbial nanowires: An electrifying tale. Microbiology 2016, 162, 2017-2028. [CrossRef] 
91. Reguera, G.; McCarthy, K.D.; Mehta, T.; Nicoll, J.S.; Tuominen, M.T.; Lovley, D.R. Extracellular electron transfer via microbial nanowires. Nature 2005, 435, 1098-1101. [CrossRef]

92. Gorby, Y.A.; Yanina, S.; McLean, J.S.; Rosso, K.M.; Moyles, D.; Dohnalkova, A.; Beveridge, T.J.; Chang, I.S.; Kim, B.H.; Kim, K.S.; et al. Electrically conductive bacterial nanowires produced by Shewanella oneidensis strain MR-1 and other microorganisms. Proc. Natl. Acad. Sci. USA 2006, 103, 11358-11363. [CrossRef]

93. Singh, A.; Srivastava, A. Mechanical Behavior of Double-Walled Carbon Nanotubesusing Molecular Dynamics. In Proceedings of the Indian Society of Theoretical and Applied Mechanics (ISTAM-2015), MNIT, Jaipur, India, 16-19 December 2015.

94. Darnton, N.C.; Berg, H.C. Force-extension measurements on bacterial flagella: Triggering polymorphic transformations. Biophys. J. 2007, 92, 2230-2236. [CrossRef]

95. Wei, X.; Chen, Q.; Peng, L.M.; Cui, R.; Li, Y. Tensile loading of double-walled and triple-walled carbon nanotubes and their mechanical properties. J. Phys. Chem. C 2009, 113, 17002-17005. [CrossRef]

96. Thornton, W.M. The electrical conductivity of bacteria, and the rate of sterilisation of bacteria by electric currents. Proc. R. Soc. London. Ser. B Contain. Pap. Biol. Character 1912, 85, 331-344. [CrossRef]

97. Wang, Y.; Weng, G.J. Micromechanics and Nanomechanics of Composite Solids; Springer: Berlin, Germany, 2018; ISBN 9783319527949.

98. Pitroda, J. A Critical Review on Carbon Nanotubes. Int. J. Constr. Res. Civ. Eng. 2016, 2, 36-42. [CrossRef] 